CONTRIBUTIONS FROM THE NEW YORK

BOTANICAL GARDEN-No. 212

\title{
SCROPHULARIACEAE OF THE LOCAL FLORA
}

Bí FRANCIS W. PENNELL

NEW YORK

1919

Reprinted, without change of paging, from TorRerA, 19: 107-119, August 7; 143-152, September 17; 161-171, October 28; 205-216, December 10, 1919; 235-242, January 22, 1920. 


$$
\begin{array}{r}
P 405 \\
1919
\end{array}
$$


[Reprinted from Torreya, Vol. 19, No. 6, June, 1919.]

SCROPHULARIACEAE OF THE LOCAL FLORA. I

By Francis W. Pennell

In commencing the systematic study of a family of plants for North America there is logic in studying first those species which occur in the eastern seaboard of the United States. These were the plants first known in detail, if not necessarily those earliest discovered, on this continent. From Massachusetts to Carolina we are on classic ground, and here the plant-life has been worked over so many times, and each species so often collected, that we may now speak with certainty of nearly all specific identities.

The present study is concerned with but a portion of this territory, the counties included within the local flora range, of the Torrey Botanical Club and of the Philadelphia Botanical Club. These combined include all of Connecticut; New York southeast of Columbia, Greene and Delaware counties inclusive; all of New Jersey; Pennsylvania southeast of Pike, Wayne, Lackawanna, Luzerne, Schuylkill, Lebanon, Dauphin and Lancaster counties inclusive; Newcastle county, Delaware; and Cecil county, Maryland. This area is in main part represented in the Torrey Club collection at the New York Botanical Garden, and the portion within approximately fifty miles of Philadelphia in the remarkably full and valuable collection of the Philadelphia Club at the Academy of Natural Sciences in that city. To both collections I have had free access, and the records below include data from these, the herbaria of Columbia University, the Brooklyn Botanic Garden, the University of Pennsylvania and several other institutions. To the curators of all I am appreciative.

Nearly all the species native or naturalized within the area 
of this study I have myself collected and of each made descriptions of fresh corollas, and noted other features to be gained only in the field. The importance of such work in taxonomic study needs emphasis.

In the present revision keys are given to the genera and species. These are detailed for points of definite contrast. These keys apply only to the species of our flora, and the warning must be made that the generic and tribal contrasts may be of little or no assistance beyond this territory. But just such keys as these are of most value to the local worker, and moreover it is by combining such analyses from various regions that we may hope ultimately to build more thorough family keys. An inductive process!

For each genus the type-species is stated. For each native species information of its type is stated, quoted from the original describer. This includes the statement of the particular specimen from which the first description was made and of the place of its collection. The later history of each name is traced. Extra-limital synonyms, even if the names have been current here, are not included except by brief mention. But all names ever proposed based upon plants occurring native in this area are supposed to be included.

With respect to distribution I should like to undertake a study for which the data at hand in our herbaria is not yet sufficient. Moreover my own observations have not as yet been sufficiently prolonged over this area. The counties best represented in herbaria are those of Connecticut; New York, from the Highlands southeastward, including all Long Island; New Jersey, with considerable gaps to the northwest; Pennsylvania southeast of the Blue Ridge; and northern Delaware. Northwest of the Highlands and of the Blue Ridge botanical collections have been few and scattered, the regions best known being the Pocono Plateau of Pennsylvania, and sections of Ulster, Greene and Delaware counties, New York.

Dr. Witmer Stone, in his Plants of southern New Jersey, has traced with a master-hand the distribution of vegetation for the Coastal Plain portion of that state. That regions of as sharp 
delimitation occur northward and westward, through the land of hills, of parallel mountain-areas with intervening trough-like valleys, of red soil derived from Triassic rock or of black soil from Ordovician limestone, of various soils derived from the ridges of shale, gneiss and sandstone, appears self-evident. In the northern portion of our territory glaciers, building lake and gravel habitats, have left us a new series of environmental conditions. Mr. Taylor's suggestive Flora does not attempt the detailed analysis of distribution which is demanded. I believe that the careful working-out of the ranges of the species of a few well-selected families of plants will give the knowledge we need for the dividing into phytogeographic areas of this varied inland-knowledge which will be nearly as definite as if multiplied by such a wealth of data as is presented by Dr. Stone. The problem is fascinating and it is with reluctance that I realize that the Scrophulariaceae have not yet been observed over a sufficient area or with sufficient thoroughness to warrant basing upon this study any contribution toward such a survey.

Our present study then attempts but these three goals: to present keys contrasting the genera and species of Scrophulariaceae in our flora, to make certain the nomenclature, and to give preliminary observations of distribution.

A. Corolla with the posterior lobes external in the bud. (Antirrhinoideae.)

B. Filaments five. Stigma capitate. Capsule septicidal. Sepals five, distinct.

C. Corolla rotate, slightly zygomorphic, its lobes much longer than the tube. Filaments all with fertile anthers. Leaves alternate.

CC. Corolla tubular-campanulate, zygomorphic, its

I. Verbasceae.

I. Verbascum. lobes shorter than the tube. Posterior filament without anther, the others didynamous. Leaves opposite.

Corolla white, lavender or pink, pubescent or puberulent within, its anterior lobes projecting. Sterile filament slender, filiform, white.

Corolla membranous, white or lavender, puberulent or somewhat pubescent within over base of anterior lobes. Sterile fila-

II. Cheloneae. 
ment as long as the others, pubescent on its posterior face. Anther-sacs distinct, glabrous or barbate with short hairs. Sepals lanceolate to ovate, acute to acuminate. Seeds wingless. Inflorescence compound, a raceme of cymosely branching lax flower-clusters. Stem-leaves clasping.

Corolla semi-fleshy, white or rose, densely pubescent within over base of anterior lobes. Sterile filament much shorter than others, glabrous. Anther-sacs becoming confluent, densely lanose. Sepals ovateorbicular, rounded. Seeds winged. Inflorescence simple, a spike-like raceme of single flowers on short several-bracted pedicels. Stem-leaves narrowed at base, short-petioled.

Corolla red-brown, glabrous within, its anterolateral lobes vertically projecting, the anterior lobe deflexed. Sterile filament shorter than wide, two-lobed, yellow or red-brown. Inflorescence compound.

BB. Filaments four or two, the posterior one being lost.

C. Acaulescent. Corolla rotate, slightly zygomorphic, white or lavender-tinged. Capsule twocelled at base, septicidal. Stigma capitate. Small herb, spreading by stolons.

CC. Caulescent, with leaves mainly cauline. Corolla zygomorphic, the lobes shorter than the tube. Capsule two-celled throughout. Inflorescence simpiy racemose.

D. Leaves opposite. Corolla without a spur. Stigma of two usually plate-like lobes. Capsule septicidal, or somewhat loculicidal by a simple split down median line of carpel.

Corolla yellow or white, with throat fourangled, its orifice open; pubescent within at base of posterior lobes. Postero-lateral stamens perfect, antero-lateral reduced to sterile filaments or wanting. Several bractlets at base of the five distinct sepals. Capsule septicidal, or tardily slightly loculicidal.

Corolla yellow or lavender-blue, with throat somewhat flattened into a horizontal plane, channeled beneath and arched

III. Limoselleae.

5. Limosella.

IV. Gratioleae.

6. Gratiola. 


\section{1}

posteriorly; pubescent within at base of anterior lobes. No bractlets below calyx.

Perfect stamens four, with slender straight filaments. Corolla $\mathrm{I}_{5}-30 \mathrm{~mm}$. long, its orifice nearly closed by the raised anterior lip; the posterior lobes rounded and nearly equaling anterior. Style without tubercle-like base. Capsule loculicidal, tardily somewhat septicidal. Sepals united over one-half length.

Perfect stamens two; the antero-lateral filaments fused with corolla ridges, from near apex of which abruptly upcurving. Corolla lavender, 2-IO $\mathrm{mm}$. long, its orifice open; the posterior lobes acute and shorter than the anterior, or else wanting. Style with white tubercle-like base. Capsule septicidal, the thin plate-like septum persisting.

Corolla 6-1o mm. long, with two posterior lobes developed. Posterolateral stamens perfect, anterolateral filaments without anthers. Sepals five, united at base. Plants erect or ascending, with leaves I-3 $\mathrm{cm}$. long.

Corolla $2 \mathrm{~mm}$. long, with two posterior lobes lost. Postero-lateral stamens lost, antero-lateral filaments with anthers. Sepals four (the posterior lost), united nearly four fifths their length. Plant repent, with leaves $.3-.5 \mathrm{~cm}$. long.

DD. Leaves alternate. Corolla with a spur at the base of the anterior petal. Stigma capitate. Capsule loculicidal, the septum with adjacent capsule-wall persisting, the remaining wall splitting irregularly.

AA. Corolla with the anterior lobes external in the bud. (Rhinanthoideae.)

B. Stamens two, the postero-laterals presert; the antero-laterals completely lost. Antero-'ateral lobes of corolla external in bud. Not parasitic. Sepals four, the posterior lost. Posterior lobes of corolla completely fused.

7. Mimulus.

8. Ilysanthes.

9. Hemianthus.

V. ANTIRRHINEAE

Io. Linaria.

Vi. Veriniceae. 
Leaves whorled. Corolla white, its lobes shorter than the tube. Capsule acute, longer than broad, not flattened. Plant Io-20 dm. tall.

Leaves opposite or alternate. Corolla blue, its lobes longer than the tube. Capsule acute to deeply notched, broader than long, flattened. Plants lower.

BB. Stamens four, didynamous, the antero-laterals usually slightly the longer. Usually parasitic on roots of other plants.

C. Sepals five, alike, more or less united. Corollalobes all somewhat distinct, the posterior spreading or broadly arched; anterior lobe external in bud. Stigma elongated. Capsule loculicidal, splitting through septum.

Corolla yellow or pink, campanulate, with inflated throat and open orifice. Stamens all perfect, the anthers two-celled, lanose. Two stigmatic lines, one down each side of style-apex. Filaments and style nearly as long as the tube of the corolla. Capsule exserted from the calyx-tube. Calyx not bracted at base.

Corolla yellow. Capsule acute to acuminate. Leaves lanceolate to ovate, entire to bipinnatifid, petioled. Stem stout, over $4 \mathrm{dm}$. tall. Perennials or annuals.

Corolla pink, with red spots within on anterior side. Capsule rounded, with a mucro. Leaves filiform to lanceolate, entire or auriculate-lobed at base, sessile. Stem slender, usually lower. Annuals.

Stem ascending-scabrellous to glabrous. Leaves linear to filiform, entire. Pedicels over I $\mathrm{mm}$. long. Calyx-lobes linear to subulate, slightly longer to usually much shorter than the tube. Corolla with two yellow lines within throat anteriorly. Anther-sacs of both pairs of stamens uniform. Capsule globose to globose-ovoid, 3-7 mm. long. Seeds closely reticulate.

Stem retrorse-hispid. Leaves lanceolate, usually auriculate-lobed at base. Pedicels less than I mm. long. Calyxlobes ovate, longer than the tube. Corolla without yellow lines within throat anteriorly. Anther-sacs of pos-

II. Veronicastrum.

12. Veronica.

Vili. Buchnereae.

13. Aureolaria.

14. Agalinis. 
terior pair of stamens shorter. Capsule broadly ovate, Io-13 $\mathrm{mm}$. long. Seeds reticulate with raised ridges.

Corolla purple-blue, salverform, the tube very narrow and densely pilose, the lobes widely spreading. Postero-lateral stamens becoming rudimentary, the antero-laterals with but one anther-sac. Stigmatic area over entire surface of style apex. Filaments and style less than one half length of corolla-tube. Capsule equaled by and enclosed within calyxtube. Calyx bibracteolate at base.

CC. Posterior sepal shorter or wanting. Corolla decidedly two-lipped, the posterior lobes united and arched nearly to apex, the anterior lobes usually shorter; anterior or one antero-lateral lobes external in bud. Stigma short, capitate.

Posterior sepal shorter than others. Capsule turgid, septicidal, only tardily slightly loculicidal. Seeds linear, flat, $2 \mathrm{~mm}$. long. Calyx bibracteolate at base.

Posterior sepal wanting. Capsule flattened, loculicidal, splitting through septum. Calyx not bracted at base.

Corolla with posterior lobes projecting, not hooded at apex, the anterior lobes very short, thickened, deep-green. Seeds many, reticulate. Bracts foliaceous, distally scarlet.

Corolla with posterior lobes arched, hooded at apex, the anterior lobes membranous, flat, colored. Seeds few, not reticulate. Bracts not colored.

Corolla yellow or pink throughout, the anterior lip not raised into a palate. Seeds more than two. Sepals of each side united nearly or quite to apex. Leaves crenate-serrate to bipinnatifid-lobed.

Corolla I $2 \mathrm{~mm}$. long. Anthers lanose. Capsule circular, equally twocelled, splitting on both posterior and anterior sides. Seeds $5 \mathrm{~mm}$. long, circular, flat, broadly winged. Sepals as long as the capsule, on each side united nearly to apex. Leaves crenate-serrate. Annual.
15. Otophylla.

16. Buchnera.

ViII. Rhinantheae.

I7. Schwalbea.

18. Castilleja.

19. Rhinanthus. 
Corolla I5-20 $\mathrm{mm}$. long. Anthers giabrous. Capsule ensiform, unequally two-celled, splitting only on posterior side. Seeds I $\mathrm{mm}$. long, oblong, cylindric, not winged. Sepals less than one half length of capsule, on each side united to apex. Leaves bipinnatifid-lobed. Perennials.

20. Pedicularis.

Corolla white, the anterior lip raised into a yellow densely pubescent palate. Seeds maturing two to four to a capsule. Sepals united at base only, the two postero-laterals longer. Leaves lanceolate, entire or setaceous-toothed near base.

21. Melampyrum.

\section{Verbascum L., Sp. Pl. I77. I753}

\section{Type species, V. Thapsus L. of Europe.}

Leaves glabrous. Stem above and calyx with simple glandular hairs. Corolla yellow or white. Filaments all densely lanose with knobbed purple hairs. Pedicels Io- $15 \mathrm{~mm}$. long. Capsule subglobose, glandular-puberulent. Seeds .8-.9 mm. long, dark-gray.

I. V. Blattaria.

Leaves, stem and calyx more or less pubescent with stellatelybranched non-glandular hairs. Corollas always yellow. Filaments: three posterior lanose, two anterior sparingly lanose to glabrous, with filiform yellow hairs. Pedicels less than ro $\mathrm{mm}$. long. Capsules ovoid or oblong, stellatepubescent. Seeds .4-.7 mm. long, brownish-gray.

Leaves dark and becoming glabrate above, whitened beneath, sessile or the lower petiolate, not decurrent. Pedicels reaching Io $\mathrm{mm}$. long, clustered three to twelve in an axil. Sepals linear, $2-2.5 \mathrm{~mm}$. long, much shorter than the mature capsule. Corolla $18 \mathrm{~mm}$. wide. Capsule 4 $\mathrm{mm}$. long. Seeds 6-7 mm. long.

2. V. Lychnitis.

Leaves dull- or yellowish-green and permanently pubescent above, scarcely paler beneath, sessile, more or less decurrent. Pedicels reaching $5 \mathrm{~mm}$. long, one to five in an axil. Sepals ovate, $6-8 \mathrm{~mm}$. long, slightly shorter than to equaling the mature capsule. Corolla 20-35 mm. wide. Capsule 6-8 mm. long. Seeds . $4^{-} .5 \mathrm{~mm}$. long.

Stem-leaves broadly ovate, strongly crenate, dull-green, moderately pubescent. Pedicels reaching $5 \mathrm{~mm}$. long, three to five to an axil. Inflorescence interrupted. Corolla $30-35 \mathrm{~mm}$. wide. 
Stem-leaves lanceolate, finely crenate, yellowish-green, very densely pubescent. Inflorescence crowded. Pedicels very short to none, one to an axil. Corolla 20-22 mm. wide.

\section{Verbascum blattaria L.}

Flowering from mid-June to mid-August, fruiting from early July on.

Loam soil, cultivated fields, common throughout the area above the Fall-line, rarely recorded from the Coastal Plain. Naturalized from Eurasia.

\section{Verbascum Lychnitis L.}

Flowering from late June to August, fruiting from August on. Loam soil, roadsides, local in the area above the Fall-line, especially near the cities. Naturalized from Eurasia.

3. Verbascum phlomoides L.

Collected in flower in July and August.

Probably sandy soil, cultivated fields; rare. Garden City, L. I.; Lindenwold, N. J. Adventitive from Eurasia.

4. Verbascum thapsus L.

Flowering from mid-July to late August, fruiting in August and September.

Mainly in loam soil, fields and roadsides; common throughout, mainly above the Fall-line. Naturalized from Eurasia.

2. Penstemon [Mitchell Schmidel, Icones Plantarum 2. I762 Type species, Chelone Penstemon L., "Habitat in Virginia."

Corolla funnelform; throat tubular; lobes widely spreading; puberulent within. Leaves entire or the upper slightly serrulate, glabrous, under a lens evidently puncticulate. Seeds strongly ridge-angled.

Corolla with throat tubular near base, then abruptly inflated; pubescent within at base of anterior lobes. Leaves more or less denticulate, not evidently puncticulate under a lens. Seeds not strongly ridge-angled.

Corolla with throat inflated, its mouth open, not closed by the anterior lip. Sterile filament slightiy to moderately densely bearded. Calyx-lobes ovate-lanceolate to lanceolate. Plants taller, glabrous to puberulent. 
Corolla white, rather strongly inflated. Anther-sacs usually barbate. Stem glabrous or nearly so.

2. P. Digitalis.

Corolla light violet-purple, moderately inflated. Anthersacs glabrous. Stem puberulent.

3. P. Pentstemon.

Corolla with throat scarcely inflated, its mouth closed by the anterior lip, which closes as a convex arc. Sterile filament very densely bearded. Calyx-lobes ovate. Plants lower, the stem pubescent or hirsute.

Corolla I 5-20 mm. long, white with violet lines. Anthersacs oval. Calyx-lobes obtuse to short-acuminate. Stem and leaves soft-canescent. Leaves lanceolate.

Corolla 23-28 mm. long, lavender-purple, unlined. Anther-sacs triangular-orbicular. Calyx-lobes acuminate to caudate. Stem and frequently midrib of leaves beneath more or less lanose-hirsute. Leaves lanceolate-attenuate.

4. P. pallidus.

5. P. hirsulus.

I. Penstemon tubiflorus Nutt.

Flowering in June.

Fields, seen only from Spring Valley, Rockland Co., N. Y. Introduced from the southwestern Mississippi Valley.

\section{Penstemon digitalis Nutt.}

Flowering from mid-June to early July, fruiting in late August and September.

Fields and meadows, frequent above Fall-line. Introduced from the southwestern Mississippi Valley.

\section{Penstemon pentstemon (L.) MacMillan.}

Flowering in June and July.

Fields and meadows, seen only from Rockland Co., New York and Bergen and Gloucester counties, New Jersey. Introduced from the South Atlantic states.

4. Penstemon pallidus Small, Fl. S. E. Un. St. io6o, I337. I903.

"Type, Bedford, N. Y., Britton, June, I900, in Herb. N. Y. B. G." Type seen; also the plant re-collected and studied at the type-station.

Flowering from mid-May to late June.

Sandy or barren soil, occasional, mostly above the Fall-Line. Certainly introduced from the central Mississippi Valley.

5. Penstemon hirsutus (L.) Willd.

Chelone hirsuta L., Sp. Pl. 6II. 1753. "Habitat in Vir- 
ginia:" Based upon Clayton n. 39 in the Gronovian Herbarium. The Linnean characterization certainly denotes the plant here considered.

Penstemon hirsutus (L.) Willd., Sp. P1. 3:227. 1800.

Flowering from late May to early July, fruiting from July on. Dry fields, usually sandy, in potassic soil, occasional or local through the area above the Fall-line. Ranges from southern Vermont and southern Ontario to upland Virginia, Kentucky and southern Michigan.*

\section{Chelone L., Sp. Pl. 6 i i. 1753}

Type species, C. glabra L.

I. Chelone glabra L., Sp. Pl. 6i i. I753. "Habitat in Virginia, Canada." Based upon a plant grown in the Clifford garden in Holland.

Chlonanthes tomentosa Raf., New Fl. Am. 2: 20. I837. "In the mts. of Virginia." Leaves tomentose or pubescent beneath; a condition of more frequent occurrence southward, specimens noted from Monmouth, Burlington and Camden counties, New Jersey, and frequently through southeastern Pennsylvania. Here treated as a form, tomentosa (Raf.) Pennell, forma nova.

Flowering from early August to early October, fruiting from mid-September on.

Moist loam to sandy woodland, in potassic soil, frequent to common throughout above the Fall-line; frequent or occasional through the Coastal Plain, outside of the Pine Barrens. The leaves tend to be narrower in the Coastal Plain. Ranges from Newfoundland to Manitoba, northern Florida and Kansas.

\section{Scrophularia L., Sp. Pl. 6ig. I753}

Type species, S. nodosa L., "Habitat in Europae succulentes."

Petioles stouter, evidently wing-margined. Leaves cuneate to truncate at base, coarsely serrate to dentate. Inflorescence narrowly elongate, $4-8 \mathrm{~cm}$. wide, its branches rela-

* Paulownia tomentosa (Thunb.) Baill.

A tree with lavender flowers, is an occasional escape from cultivation to roadsides, railroad-banks and thickets. Adventive from eastern Asia. 
[Reprinted from 'TorReYa, Vol. 19, No. 8, August, 1919.]

SCROPHULARIACEAE OF THE LOCAL FLORA. II By Francis W. Pennell

5. Limosella L. Sp. P1. 631. I753.

Type species, L. aquatica L., of Europe.

I. Limosella subulata Ives in Trans. Phys. Med. Soc. N. Y. I : 440. I8I7. "First observed in I8I6. . . It flourishes in great abundance in the Housatonic, and in most of the rivers which empty into Long Island Sound, within the range of the tide."

Ygramela (or Limosella) maritima Raf. Atl. Journ. I99. I833. "Discovered this year in the wet sand of the sea islands of New Jersey." As a new genus, this was based upon specimens the flowers of which bore but two stamens. Certainly an abnorma ${ }^{1}$ form, as the plant of such situations has normally four stamens.

Flowering from late August to November, and soon ripening fruit.

Tide-water river-beaches, saline, brackish or fresh, and about borders of ponds, brackish or fresh, along the coast. Margins of ponds back of sand-dunes, growing inundated or somewhat emersed on the sandy coastward margin of these, Long Island and southward to Ocean County, New Jersey; on the sandy or gravelly flats between high and low tide, along the Housatonic, Hudson, Passaic, Delaware, and doubtless other rivers. The plants of the two environments differ slightly, as has been indicated in Torreya 19: 5I. I9I9. This species ranges from Labrador to Maryland. 
6. Gratiola L. Sp. Pl. i7. 1753.

Type species, G. officinalis L., of Europe.

Corolla slightly exceeding calyx, externally glabrous. Capsule nearly pyramidal, acuminate. Pedicels very short. Stem pubescent with several-celled hairs. (Pilosae.) Corolla more than twice as long as the calyx, externally more or less puberulent. Capsule broader, acute to rounded. Pedicels longer. Stem glabrous or puberulent with onecelled hairs, these frequently gland-bearing.

Pedicels exceeding ro $\mathrm{mm}$. in length. Corolla within throat on posterior side densely pubescent with knobbed hairs. Capsule ovate, equaled or exceeded by the sepals. Seeds $3-5 \mathrm{~mm}$. long, semiglobose to oblong.

Capsule I-3 mm. long, exceeded by the sepals. Stem-leaves clasping by a broad base, usually at least the upper with resinous dots. Roots perennial, slender. Stoloniferous. (Ramosae.)

Corolla golden-yellow throughout. Capsule $3 \mathrm{~mm}$. long, little exceeded by the sepals. Leaves lanceolate to nearly ovate, entire or distally obscurely denticulate, with blackish glandular dots.

Leaves linear to lanceolate, frequently denticulate distally, usually strongly puncticulate. Sepals obtusish to acute.

Leaves lanceolate to nearly ovate, entire, obscurely puncticulate distally. Sepals very obtuse.

I. G. pilosa

2. G. aurea.

2a. G. aurea obtusa.

Corolla with throat dull-yellow, the lobes white. Capsule $2 \mathrm{~mm}$. long, much exceeded by the sepals. Leaves ovate, serrate, the upper sometimes with sparse glandular dots.

Capsule 4-5 $\mathrm{mm}$. long, about equaled by the sepals. Stem-leaves narrowed to a sessile or slightly clasping base, not resinous-dotted. Roots annual, the main root thick and giving off numerous fibers. Not stoloniferous. (Neglectae.)

Pedicels less than $5 \mathrm{~mm}$. in length. Corolla within throat on posterior side pubescent with knobless hairs. Capsule globose, 5-6 mm. long, slightly exceeding the sepals. Seeds $7 \mathrm{~mm}$. long, linear. Leaves and root as in Neglectae. (Virginianae.)

3. G. viscidula.

4. G. neglecta.

5. G. virginiana.

I. Gratiola pilosa Michx. Fl. Bor. Am. I: 7. I803. "Hab. in Carolinae inferioris uliginosis." Description sufficiently distinctive. 
Sophronanthe pilosa (Michx.) Small, Fl. S.E. Un. St. I067, I338. I903.

Flowering mid-July to late September, and soon ripening fruit.

Moist sandy pineland, in potassic soil, Cape May District and locally in Camden County in the Middle District, of the Coastal Plain of southern New Jersey. Ranges from New Jersey to Florida and eastern Texas, in the Coastal Plain.

2. Gratiola aurea Pursh, Fl. Am. Sept. I: I2. I8I4. "In sandy wet places, in the pine-barrens of New England, New Jersey and Carolina ... v. v.; v. s. in Herbario Banksiano." Description distinctive, rere restricted to the northern first-mentioned plant.

Flowering from early June to late September, and soon ripening fruit. Apparently fruit is sparingly matured, the plant increasing mainly by stolons.

Wet sandy potassic soil, margins of ponds; frequent in the Coastal Plain of Long Island and New Jersey, especially in the Pine Barrens; occasional about lakes in the glaciated region above the Fall-line, at least at Lake Hopatcong, Morris Co., New Jersey. Ranges from Maine and eastern Ontario to Virginia.

2a. Gratiola aurea obtusa Pennell, var. nov.

Plant erect, I.5 dm. tall. Leaves lanceolate to ovate, $\mathrm{I} .5 \mathrm{~cm}$. long, entire, obscurely puncticulate distally. Sepals $3 \mathrm{~mm}$. long, very obtuse. Corolla Io-12 mm. long.

Type, gravelly shores of Delaware River, between high and low tide, Fish House, Camden Co., New Jersey, collected in flower, July 24, Iç05, by Stewardson Brown; in herb. Academy of Natural Sciences of Philadelphia.

Gravelly or sandy shores of Delaware River, between tides, Mercer and Camden counties, New Jersey, and Philadelphia Co., Pennsylvania.

3. Gratiola viscidula Pennell, nom. nov.

Gratiola viscosa Schwein.; Le Conte in Ann. Lyc. N. Y. I: I06. I824. "Inhabits Virginia, and the upper parts of North Carolina." Apparently the plant now considered, although the description appears inaccurate in stating 
that the capsule is as long as the sepals. Not G. viscosa Hornem. Enum. Pl. Hort. Hafn. I9. I807.

Flowering from mid-July to September, and soon ripening fruit.

Swales and swamps, along streams, in potassic soil, at a few stations in the Piedmont of northern Delaware. Ranges from Delaware to upland Georgia and eastern Tennessee.

4. Gratiola neglecta Torr. Cat. Pl. N. Y.89. i8I9. "Within thirty miles of the City of New York." In the herbarium of Columbia University are two sheets, probably representing but one collection, both labeled "Gratiola virginica Linn., Torr. F1. N. Y., 2, p. 37." It is possible that one or both of these are Torrey's plants of G. neglecta. The latter was described as distinct from G. virginiana because of the lack of the rudimentary antero-lateral filaments. Five years later, in his Flora of the Northern States, Torrey was persuaded that this lack was true of $G$. virginiana, and on that account reduced his earlier species. Still later, in $\mathrm{I} 843$, in his Flora of New York, he described such rudiments as present, and held as erroneous his previous observations. The truth, as confirmed by an extensive examination of fresh flowers, is that these rudiments may be small, or reduced to one, or altogether absent; all stages are to be found in the same colony. The name is here used for the species which has long been known as $G$. virginiana.

Conobea borealis Spreng. in Neue Entdeck. 3: 26. I 822. "Hab. in locis humidis prope Noveboracum. ..." This is virtually a re-description of Gratiola neglecta Torr., although sufficient new matter is added to indicate that Sprengel must have seen a specimen of this. The change of generic classification is doubtless due to the discovery of sterile rudiments of the antero-lateral filaments.

Flowering from late May to late September, and soon ripening fruit.

Wet loam, woodland or open, in potassic soil, common above the Fall-line; and through the Middle District of the Coastal 
Plain. Ranges from Maine and Quebec to British Columbia, southward to Georgia, Texas and California.

5. Gratiola virginiana L. Sp. Pl. i7. i753. "Habitat in Virginia." Although Linné had specimens of the plants here called G. neglecta in his herbarium in 1753 , his description is taken solely from Gron. Fl. Virg. 6, I 743, and so is based upon Clayton 379. This, as shown by Dr. S. F. Blake in Rhodora $20: 65$, 1918 , is the plant which has been known as G. sphacrocarpa Ell.

Flowering from mid-May to September, and soon ripening fruit.

Wet loam, in shade, occasional in the Middle and Cape May Districts of the Coastal Plain of New Jersey, and below the Falline in Delaware. From Burlington, N. J. southward to Florida and Texas, extending inland to the southern Appalachians.

\section{Mimulus L. Sp. Pl. 634. I753 \\ Type species, $M$. ringens $\mathrm{L}$.}

Corolla yellow. Capsule dehiscent laterally, apex persistent and valves permanently attached to axial cell-wall. Seeds ellipsoid-orbicular. Stems pubescent. Species introduced.

(Simiolus Greene.)

Corolla $12-20 \mathrm{~mm}$. long. Leaves $3-4 \mathrm{~cm}$. long. Stems loosely lanose, slender, lax.

Corolla $30-35 \mathrm{~mm}$. long. Leaves $4^{-5} \mathrm{~cm}$. long. Stems glabrous to finely glandular-pubescent, stout, erect.

I. M. moschatus.

2. M. guttatus.

Corolla lavender-violet. Capsule dehiscent laterally from very apex, and its valves splitting from the persistent axial cellwall. Seeds oblong. Stems glabrous. Species native.

(Eumimulus.)

J.eaves ovate, petioled. Angles of stem slightly winged. Pedicels stout, in fruit 5-10 $\mathrm{mm}$. long. Calyx-lobes setaceous-tipped, I-2 mm. long. Corolla $35 \mathrm{~mm}$. long. Seeds pale-yellow.

3. M. alatus.

Leaves lanceolate, clasping. Angles of stem not winged. Pedicels slender, in fruit $30-60 \mathrm{~mm}$. long. Calyx-lobes lanceolate, $3-5 \mathrm{~mm}$. long. Corolla $30 \mathrm{~mm}$. long. Seeds brownish.

4. M. ringens.

I. Mimules moschatus Dougl.

Aquatic in running streamlets or in bogs; rare; seen only from Queens and Sullivan counties, New York and Lehigh County, 
Pennsylvania. Certainly an escape from cultivation on Long Island, but in the mountain habitats it appears as if native. A native of the Rocky Mountains, occurring eastward in northern Michigan, Newfoundland and northern New England.

2. Minulus guttatus DC.

Meadows and along streams, rarely escaped from cultivation; seen from Litchfield County, Connecticut, and Delaware County, New York. Native of western North America.

3. Mmulus alatus Ait. Hort. Kew. 2: 36I. i789. "Nat. of North America. Introd. I783, by Mr. William Malcolm."

Flowering from late July to early September, and soon ripening fruit.

Shaded swamps and along streams, in potassic soil, frequent, becoming rare northward, through the area above the Fall-line; occasional in the Middle District of the Coastal Plain of New Jersey. Ranges from Connecticut to Ontario and Kansas, southward to Florida and Louisiana.

4. Mimulus Ringens L. Sp. Pl. 634. I753. "Habitat in Virginia, Canada . . . Hort. ups. I76. t. 2." In the Hortus Upsalensis I76, pl. I, I748, Linné described and figured our plant.

Flowering from early July to mid-September, and soon ripening fruit.

Open swales and along streams, more rarely in shaded swamps, in potassic and calcareous soils, common throughout the area above the Fall-line, of more rare occurrence through the Middle District and Coast Strip of the Coastal Plain. Ranges from Nova Scotia to Alabama, Minnesota and Kansas.

\section{Ilysanthes Raf. Ann. Nat. I3. I820}

Type species, $I$. riparia Raf., of the Ohio valley.

Leaves I-3 cm. long, obviously attenuate at base. Pedicels relatively stout, at least in fruit, shorter than the bracts. Sepals usually finely pubescent, usually about equaling the capsule.

Leaves lanceolate to ovate-lanceolate, usually only the lowermost obtuse. Fruiting pedicels $5^{-10} \mathrm{~mm}$. long. Plant diffuse. 
Leaves elliptic-oval, all obtuse. Fruiting pedicels 3-5 $\mathrm{mm}$. long. Plant erect.

Ia. I. dubia inundata.

Leaves $.5^{-1.5} \mathrm{~cm}$. long, rounded at base, or at least broadest much below the middle. Pedicels filiform, longer than the bracts. Sepals glabrous or nearly so, shorter than the capsule.

2. I. inaequalis.

I. Ilisanthes dubia (L.) Barnhart.

Gratiola dubia L. Sp. Pl. I7. I753. "Habitat in Virginiae aquosis." Type, Clayton I64, identified by Dr. B. L. Robinson in Rhodora 10: 67. I908, as the species here considered.

Capraria gratioloides L. Syst. ed. X. III7. I759. Based upon Gratiola dubia L.

Ilysanthes gratioloides (L.) Benth. in DC. Prod. I0: 419. I 846.

Lindernia gratioloides (L.) Lloyd \& Fouc. Fl. Ouest Fr. ed. IV. 246. I886.

Ilysanthes dubia (L.) Barnhart in Bull. Torr. Club 26: 376 . 1899.

Flowering from early July to October, and soon ripening fruit.

Swamps, in potassic soil, frequent above the Fall-line and in Middle and Cape May Districts of the Coastal Plain. Ranges from New Brunswick and Ontario to Florida and Texas.

ra. Ilysanthes dubia inundata Pennell, var. nov.

Plant erect, I.5-2 dm. tall. Leaves elliptic-ova!, obtuse, I.5$2 \mathrm{~cm}$. long Pedicels in fruit but $3^{-5} \mathrm{~mm}$. long.

Type, sandy tidal flats of Delaware River above Delair, Camden Co., New Jersey, collected in fruit September 3, I9I5, Pennell 6496; in herbarium New York Botanical Garden.

Tidal flats of Passaic River, New Jersey, of the Delaware River in New Jersey, Pennsylvania and Delaware. Also seen from along the Potomac River near Alexandria, Virginia.

2. Ilysanthes inaequalis (Walt.) Pennell, comb. nov.

Gratiola inaequalis Walt. F1. Carol. 6I. I788. Probably from lower South Carolina, a district where the plant here considered is frequent. Identified by Michaux, Fl. Bor. Am. I : 7. I 803 as questionably his own Gratiola 
anagallidea, and by Elliott, Sketch Bot. S. C. \& Ga I : I6. I8I6, identified and carefully described under the name Lindernia dilatata Muhl. Both the latter specific names are synonyms of this.

Flowering from late June to late September, and soon ripening fruit.

Swamps, in potassic soil, frequent throughout the Coastal Plain excepting the Pine Barrens, and, occasionally extending somewhat above the Fall-line. Ranges from Massachusetts to Florida and Texas.

9. Hemianthus Nutt. in Journ. Acad. Nat. Sci. Phila. I: II9. I 817 .

Type species, $H$. micranthemoides Nutt.

I. Hemianthus micranthus (Pursh) Pennell, comb. nov.

Herpestis micrantha Pursh, Fl. Am. Sept. 2: 4I8. I8I4. "On the banks of rivers, at the edge of low water mark: Pennsylvania to Virginia." Described as with fiveleaved calyx, but no other plant can possibly be intended. Hemianthus micranthemoides Nutt. in Journ. Acad. Nat. Sci. Phila. I: II9. pl. 6. I8I7. "Habitat on the gravelly banks of the Delaware, overflowed by the tide, near Kensington [Pennsylvania]." Type seen in the herbarium of the Academy of Natural Sciences.

Micranthemum micranthum (Pursh) Wood, Class-Book 525. I $86 \mathrm{I}$.

Micranthemum Nuttallii A. Gray, Man. Bot. N. Un. St. ed. V. 331. 1867. "Hemianthus micranthemoides Nutt.

... Tidal muddy banks of the Delaware River, and southward." Typified by plant of Nuttall.

Micranthemum micranthemoides (Nutt.) Wettst. in Engl. \& Prantl, Natür. Pflanzenfam. $4^{3 \mathrm{~b}}: 77$. I 891 .

Globifera micranthemoides (Nutt.) Kuntze, Rev. Gen. 46I. I89I.

Flowering from early September to October, and soon ripening fruit.

Gravelly or sandy river-shores, between high and low tides, 
Delaware and Chesapeake drainage. Along the Delaware River in New Jersey, Pennsylvania and Delaware. Also a'ong the Potomac River in Virginia.

Io. Linaria Mill. Gard. Dict. ed. IV. 1754

Type species, Antirrhinum Linaria L. of Europe.

Corolla, excluding spur, I5-18 mm. long, yellow; posterior lip arched over anterior; anterior lip forming a conspicuous protruding orange palate; spur tapering from a broad stout base. Capsule Io $\mathrm{mm}$. long, much exceeding the sepals. Style 8 $\mathrm{mm}$. long. Seeds $1.7 \mathrm{~mm}$. long, flattened and circularly broadly'-winged. Stem 3-Io dm. tall, densely leafy; without sterile prostrate branches from the base.

(Linaria, sensu strictu.)

I. L. Linaria.

Corolla, excluding spur, 7-8 mm. long, blue; posterior lip erect; anterior lip broadly spreading, but not forming a definite raised palate; spur very slender throughout. Capsule $2 \mathrm{~mm}$. long, equaling to slightly exceeding the sepals. Style $.8 \mathrm{~mm}$. long. Seeds $.3-\cdot 4 \mathrm{~mm}$. long, cylindric, prismatic-angled, not winged. Stem very slender, $2-8 \mathrm{dm}$. tall, less leafy; with sterile prostrate branches from base.

(Leptoplectron, sect. nov.)

2. L. canadensis.

I. Linaria Linaria (L..) Karst.

Linaria pensylvanica Scheele in Flora 26: 586 . 1843. "Aus Pensylvanien." Described as differing from L. vulgaris ( = L. Linaria) by having the raceme axis and pedicels quite smooth instead of glandular-pubescent. L. Linaria varies freely between these two states.

Loam or sandy soil, fields and waste ground, common above the Fall-line, less common through the Coastal Plain. Naturalized from Eurasia.

2. Linaria Canadensis (L.) Dum.-Cours.

Antirrhinum canadense L. Sp. Pl. 618. I753. "Habitat in

Virginia, Canada." Specimen in Linnean herbarium credited to Canada should be the type. This is probably a plant collected by Kalm, and as Kalm spent much time near Philadelphia, especially on Raccoon Creek, Gloucester Co., New Jersey, in a district where this plant is very common, his specimen is probab'y from there. In Kalm's Travels I: 358 . I770, this species is mentioned as if 
common at Raccoon. Moreover it is a plant of rare occurrence and obviously recent introduction in any part of Canada.

Linaria canadensis Dum.-Cours. Bot. Cult. 2: 96. 1802. "Lieu. Le Canada, la Virginie." Doubtless based upon Antirrhinum canadense L.

Flowering from late April to October, and soon ripening fruit.

Open sandy potassic soil, frequently a weed; thoughout the Coastal Plain of Long Island and New Jersey, but likely introduced into the Pine Barrens; above the Fall-line occasionally introduced along railroad-tracks. Ranges from Massachusetts to Florida and Texas. ${ }^{*}$ Linaria canadensis occurs occasionally in a pink-flowered form.

* The following plants are to be considered as scarcely established.

Cymbalaria Cymbalaria (L.) Wettst., from Eurasia, is occasional along roadsides, and elsewhere near old gardens.

Kickxia Elatine (L.) Dumort. and K. spuria (L.) Dumort., both from Eurasia, are occasionally seen, mostly on ballast. 
[Reprinted from Torreya, Vol. 19, No. 9, September, 1919.]

SCROPHULARIACEAE OF THE LOCAL FLORA. III

By Francis W. Pennell

iI. Veronicastrum Heister; Fabr. Enum. meth. pl. Hort. Helmstead. I I I. I 759

Type species, Veronica virginica L.

i. Veronicastrum virginicum (L.) Farwell.

Veronica virginica L. Sp. Pl. 9. I753. "Habitat in Virginia." Grown in the Clifford garden.

Veronicastrum album Moench, Meth. 437. I794.

Veronica virginica L."

Calistachya alba Raf. in Med. Repos. N. Y. II. Hex. 5:352. 1808 .

Based on Veronica virginica L. Type of Calistachya Raf., not Callistachys Vent., I804.

Leptandra virginica (L.) Nutt. Gen. N. Am. Pl. I: 7. I8I8. Type of Leptandra Nutt.

Eustachya alba (Raf.) Raf., Cat. I4. I824. Eustachya Raf. in Am. Mo. Mag. 4: I90. I8I9, was a new name for Calistachya Raf. Preoccupied by Eustachys Desv., I8Io.

Leptandra alba Raf. Med. Fl. 2: 21. I830. "The true $V$. virginica of $\mathrm{L}$. ........ The most common species being found all over the United States."

Paederota virginica (L.) Torr., Fl. N. Y. 2: 44. 1843.

Calistachya virginica (L.) Farwell in Mich. Acad. Sci. Rep. I 7 : 176. I915.

Veronicastrum virginicum (L.) Farwell, Drugg. Circ. 6r : 23I. I9I 7. 
Varying, in number of leaves in whorl (five, reducing to four or three), in inflorescence of one or several racemes, and in leaves from lanceolate to nearly ovate, pubescent to nearly or quite glabrous beneath.

Flowering from mid-July to early September, and soon ripening fruit.

Sandy or loam soil, swales and moist meadows, in potassic, magnesian and calcareous soils, frequent above the Fall-line; in western Long Island, and occasional in Middle district of New Jersey. Ranges from Connecticut and Ontario to Mississippi, Minnesota and Texas.

\section{Veronica L. Sp. Pl. 9. I753}

Type species, Veronica officinalis L., of Europe.

Flowers solitary, axillary, frequently approximating so as to form a terminal raceme. Leaves alternate through the inflorescence.

Filaments not exceeding the lobes of the corolla.

Bracts leaf-like or slightly reduced. Plants less than $3 \mathrm{dm}$. tall.

Pedicels longer than the sepals, usually exceeding the bracts. Sepals ovate. Capsule turgid. Seeds few, I.3-3 mm. long, convex-arched, roughened. Leaves petioled (rarely the uppermost sessile), primarily palmately $5^{-7}$ nerved, the midvein usually with some radiating pinnate veins; mainly alternate, the lower sometimes opposite.

Leaves broadly cordate, $3-5$ lobed, the lobes rounded. Sepals broadly ovate, conspicuously ciliate. Capsule very turgid, scarcely notched at apex, only .slightly 2-lobed. Seeds $2.5-3 \mathrm{~mm}$. long, blackish.

Leaves ovate, serrate to dentate. Sepals more shortly ciliate. Capsule slightly flattened, deeply notched at apex, thus strongly two-lobed. Seeds I.3-I.5 $\mathrm{mm}$. long, brown.

Petals not exceeding the ovate sepals. Capsule-lobes rounded, the most distal point of each about midway between the style and the lateral margin.

I. V. hederaefolia.

2. V. agrestis. 
Petals exceeding the narrowly ovate sepals. Capsule-lobes acutish, the most distal point of each near the lateral margin.

Pedicels shorter than sepals or bracts. Sepals linear to narrowly ovate. Capsules flattened. Seeds many, less than I mm. long, flat, smooth or nearly so. Leaves sessile (or the lower petioled), scarcely palmate; alternate only through the inflorescence.

Perennials. Repent, with ascending stems. Leaves oval or ovate, obscurely crenate. Inflorescence spike-like, restricted to the distal portion of the stem. Sepals ovate. Corolla blue or white, with deep-blue lines on posterior side. Capsule retuse or shallowly notched, glandular-pubescent.

Leaves prevailingly oval. Stems distally and pedicels minutely pubescent with appressed hairs. Corolla $2 \mathrm{~mm}$. long, white, with blue lines on posterior side.

Leaves prevailingly ovate. Stems distally and pedicels finely pubescent with mostly spreading hairs. Corolla $3 \mathrm{~mm}$. long, blue on posterior side, anterior lobe nearly white; with deepblue lines on posterior side.

3. V. Tournefortii.

4. V. serpyllifolia.

5. V. ruderalis,

Annuals. Erect, much branched below. Most leaf-axils flower-bearing. Sepals lanceolate to linear. Capsule deeply notched.

Lower stem-leaves ovate, crenate-serrate, the lowermost frequently petioled. Corolla deep violet-blue. Capsule pubescent with slightly gland-tipped hairs. Plant pubescent with glandless hairs.

6. V. arvensis.

Lower stem-leaves oblanceolate, entire or distally remotely toothed, all sessile. Corolla whitish throughout. Capsule glabrous. Plant glabrous or with short glandtipped hairs.

Stem glabrous.

7. V. peregrina. 
Stem pubescent with gland-tipped hairs.

Filaments much exceeding the lobes of the corolla.

Bracts linear, abruptly reduced from the lanceolate foliage-leaves. Plants 6-ro dm. tall. Perennial.

Flowers all in axillary small-bracted racemes. Leaves opposite throughout. Perennials.

Stem, pedicels, leaves and sepals pubescent. Capsules pubescent. Leaves oval or ovate, serrate to dentate. Plants of dry soil.

Leaves sessile or nearly so, ovate, dentate, the largest cordate at base. Sepals 4-5 $\mathrm{mm}$. long, linear-lanceolate, exceeding the capsule. Capsule not glandular, its lobes broadly rounded. Ascending or erect.

Stem erect, 3-5 dm. tall. Leaves coarsely dentate. Racemes 30-6o flowered, the pedicels scarcely exceeding the bracts. Largest corolla-lobes ovate, $6 \mathrm{~mm}$. long, violet.

Stem ascending, I-3 dm. tall. Leaves crenately dentate. Racemes Io-20 flowered, the pedicels much exceeding their bracts. Largest corolla-lobes nearly orbicular, 3.5-4 $\mathrm{mm}$. long, violetblue.

Leaves oval, crenate-serrate, narrowed to a petiolar base. Sepals $2-3 \mathrm{~mm}$. long, lanceolate, shorter than the capsule. Capsule glandular, the most distal point being near the lateral margin of each lobe. Extensively repent, at apex ascending.

Stem, pedicels, leaves and cepals glabrous (or in $V$. glandifera slightly pubescent with glandtipped hairs). Capsules glabrous. Leaves oblong-ovate to linear, obscurely crenateserrate to entire. Aquatics.

Capsule scarcely or not wider than long, and scarcely or not two-lobed. Sepals equaling the capsule. Leaves oblong-ovate to broadly lanceolate, obscurely crenateserrate.

Leaves all petioled.' Racemes usually ro25 flowered. Plant emersed.

Leaves sessile and clasping (or only the upper or lowermost petioled). Ra- 7a. V. peregrina xalapensis.

8. V. longifolia.

9. V. Teucrium.

Io. V. Chamaedrys.

I I. V. officinalis.

I2. V. americana. 
cemes usually longer, 25-50 flowered. In deeper water, usually mostly submersed.

Stem distally, rachis and pedicels glabrous. Leaves oblong-ovate, mostly broadest about the middle, the lowest, especially if submersed, narrowing to a petiolar base.. Capsule globose-ovoid, not or scarcely emarginate.

I3. V. Brittonii.

Stem distally, rachis and pedicels sparsely pubescent with glands, borne upon jointed stalks. Leaves lanceolate, broadest near the base, the lowest submersed ones elongated-lanceolate, clasping. Capsule broad-globose, emarginate.

I4. V. glandifera.

Capsule much wider than long, strongly twolobed. Sepals shorter than the capsule. Leaves linear or nearly so, remotely setaceous-toothed to entire.

I5. V. scutellata.

I. VERONiCA hederaEFolia L.

Occasionally introduced into waste ands, mostly near cities. From Eurasia.

2. Veronica Agrestis L.

Occasionally introduced into waste land, mostly near cities. From Eurasia.

3. Veronica Tournefortil C. C. Gmel.

Veronica precox Raf. Atl. Journ. 79. I832. "Grown in the [Bartram's Botanic] Garden [near Philadelphia] from seeds received from a place unknown; but has spread all over the garden like a weed, and even is become spontaneous on the banks of the Schuylkill." Not $V$. praecox All., I 789 .

Veronica diffusa Raf., New Fl. Am. 4:38. I838. "Native of _ naturalized on the Schuylkill near Philadelphia." Re-naming of $V$. precox Raf.

Occasionally introduced into waste land. From Eurasia.

4. Veronica serpyllifolia L.

Common in moist grassy soil, meadows, fields and lawns. From Eurasia. 
5. Veronica ruderalis Vahl, Enum. Pl. i:66. I805. "Habitat in ruderatis versuris et humidis locis frigidis Peruviae." Type not seen nor verified, but specimens from Ecuador and those collected by the writer in Colombia show the identity of this with the plant here considered.

This is the plant identified in the seventh edition of Grays Manual as Veronica humifusa Dickson. This species, published in Trans. Linn. Soc. 2: 288. I794, and found by James Dickson on "very high mountains of Scotland," was described by him as a plant wholly prostrate, with cordate-subrotund minutely scabrous leaves which often occur in threes or fours, and with a short raceme of a few crowded flowers. Whatever this may be, it surely cannot be our plant.

Veronica ruderalis appears to be the most cosmopolitan species of the genus, and doubtless $V$. serpyllifolia must be considered as a Palaearctic derivative from it. It is a boreal or mountain species through Eurasia and the Americas. One European description which I have had no opportunity to see, that of Veronica neglecta F. W. Schmidt, Fl. Boem. I : I2. I794, may give a name which possibly must supersede ours. This is identified by Koch, Syn. Fl. Germ. \& Helv. 529. I837, as a larger ovate-leaved form of $V$. serpyllifolia. However in the fifth (Hallier's) edition of the Flora von Deutschland of Schlechtendahl and Others, I7: I50, while this is similarly characterized, the glandular-pubescent plant is distinguished as var. borealis Laestad. So it would appear safer to consider neglecta as but a robust state of the appressed-pubescent serpyllifolia.

I agree with Prof. Fernald, in Rhodora 4: 194. I902, that "the evidence at hand indicates that this large-flowered variety is the only indigenous form of $V$. serpyllifolia in Northeastern America." I follow his later judgment as expressed in the Grays New Manual, and in Rhodora I3: I24. I9I I, in according this specific rank. However I see no basis for the decision of the new Gray that serpyllifolia is likewise indigenous. Its occurrence in North America is south of the region normally occupied by species common to both this continent and Europe.

Apparently this has been collected in our range by $C$. F . 
A ustin in Sullivan Co., New York in $\mathbf{1} 860$. It was labeled by him "large form."

6. Veronica artensis L.

Common in cultivated soil. From Eurasia.

7. Veronica peregrina L. Sp. Pl. I4. 1753. "Habitat in Europae hortis, arvisque." Described, as the specific name would suggest, from specimens of an introduced plant.

Certainly American in origin, but it is difficult or impossible to say of what portion of this hemisphere it is indigenous. An abundant weed in moist cultivated soil.

7a. Veronica peregrina xalapensis (H. B. K.) Pennell, comb. nov.

Veronica xalapensis H. B. K., Nov. Gen. et Sp. 2: 389. I8I\%. "Crescit in Regno Mexicano prope Xalapa (alt. 630 hex.), in nemoribus Liquidambaris Styracifluae."

Occasional in cultivated soil. In the western half of the continent this glandular-pubescent plant completely replaces true peregrina. In the east it is only occasionally seen, and that probably as an introduction. Intergradation to the species seems to be complete.

8. Veronica LONGifolia L.

Rare in waste land. From Eurasia.

9. Veronica Teucrium L.

Rare in grass or waste land. From Eurasia. io. Veronica Chamaedrys L.

Occasional in grass land. From Eurasia.

II. Veronica officinalis L.

Common in pasture fields and waste lands. In colonial times this was grown as a medicinal plant, and very early became established as if native. From Eurasia.

I2. Veronica Americana Schwein.

Veronica Beccabunga americana Raf., Med. F1. 2: 109. I830. "It grows from Canada to Virginia and Kentucky, near water, brooks, \&c."

Veronica americana Schwein.; Benth. in DC., Prod. Io: 468. I846. "Veronica americana (Schweinitz! mss.) 
... In America boreali a Canada et Carolina usque ad flum. Oregon et in ins. Sitcha... (v. s.)" Specimen seen in herbarium of the Academy of Natural Sciences of Philadelphia, labeled "Bethl." [Bethlehem, Pennsylvania], collected by Schweinitz, may be of collection seen by Bentham.

Flowering from late May to mid-August, and soon ripening fruit.

Springheads in woodland, and along cool streams, in potassic soil, frequent throughout the area above the Fall-line; in northern and westernmost Long Island. Ranges from Quebec to Alaska, south to South Carolina, New Mexico and California.

\section{I3. Veronica Brittonii Porter sp. nov.}

Veronica Anagallis latifolia Britton in Bull. Torr. Bot.

Club I2: 49. I885. "In the latter part of September, I883, ‥ near Mahwah, Bergen Co., New Jersey, I noticed [this] in a small stream which crosses the N. Y. L. E. \& W. R. R., half a mile or so north of the station." Type seen in herbarium of Columbia University at the New York Botanical Garden.

Stem 3-9 dm. long, glabrous, succulent, hollow. Leaves oblong-ovate to oval, acute, crenate-serrate to nearly entire, $5^{-10} \mathrm{~cm}$. long, $3^{-5} \mathrm{~cm}$. wide, clasping, the lowest narrowed to a petiolar base. On autumnal shoots all the leaves are ovate and definitely petioled. Racemes axillary to the upper leaves, 6-12 cm. long, 40-60 flowered. Bracts narrowly lanceolate, 4-5 mm. long. Pedicels $3.5-4.5 \mathrm{~mm}$. long, glabrous. Sepals 3-3.5 mm. long, lance-ovate, acute. Corolla $4 \mathrm{~mm}$. long, with a few hairs within throat, pale-blue, paler anteriorly, with longitudinal reddish-violet lines. Capsule $3-3.5 \mathrm{~mm}$. long, globoseovoid, acutish. Seeds $.4 \mathrm{~mm}$. long, oval, yellow-brown.

Type, base of Marble Hill, above Phillipsburg, New Jersey, collected in flower and fruit June 24, I 892, T. C. Forter; in herbarium Columbia University at the New York Botanical Garden. This specimen shows the summer state. Specimens collected at the same station October 9, I892, show excellently the autumnal condition.

In the herbarium of Columbia University is a manuscript 
description by Dr. Thomas C. Porter, the diagnosis of which includes such field knowledge as to make it worth quoting in full: "Veronica Brittonil, n. sp.

" (V. Anagallis L., var. latifolia Britton). Glabrous, perennial, growing in shallow, shaded rivulets. In its summer state (June), the stems are erect, simple or branching, 2 to 3 feet high, round, of ten half an inch in diameter, succulent, fistular, brittle; the leaves ovate or oblong-ovate, variable in size, 2 to 3 inches in length, more or less clasping at base, the lowest pair sometimes contracted in to short petioles; racemes numerous, many-flowered. In its autumn-state (October), the stems are procumbent at base and rooting at the joints, rarely producing racemes of flowers; the leaves large, orbicular, $1 \frac{1}{2}$ to 2 inches in diameter, abruptly narrowed into broadly margined petioles, $1 / 2$ to an inch long, shining, thickish when fresh, with prominent veins beneath, thin when dried, crenulate, those of the slender branches similar but much smaller, petioles of the uppermost very short or wanting. Inflorescence, fruit and seeds scarcely to be distinguished from those of $V$. Anagallis and $V$. Beccabunga; flowers pale blue, the three large lobes marked with reddish stripes; capsules orbiculate, acutish." Then follow citation of specimens from northeastern Pennsylvania and northwestern New Jersey, and considerable interesting comment.

From a series of letters of Dr. Porter to Dr. Britton, the history of the former's interest in this plant may be traced. It commenced with finding on October I, I89I at Pot Rock, near Easton, Pennsylvania, a colony of the autumnal petioled-leaved

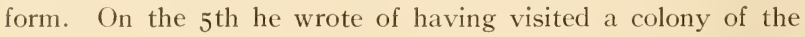
plant in "the little run beside the tavern above Pot Rock," a station whence in "in midsummer two or three years ago" he had obtained "a very different form." The plant was abundant, and exactly that of the first discovery. On the I 2 th, Dr. Porter was "fully convinced that this plant is genuine $V$. Beccabunga, L.," and accordingly sent a note for the Torrey Bulletin to urge this opinion. He had even convinced himself of its introduction from the Old World. But for us the most interesting paragraph of this note is that contrasting the autumnal state of this plant with Veronica americana: 
"Veronica Americana Schwein., a nearly allied species, which has likewise petioled leaves, was growing with it in some places, but its procumbent, far less robust stems and its smaller, ovate or lance-ovate, sharply serrated leaves furnished a striking contrast. In seeing them thus together even an unpracticed eye could not have failed to distinguish the one from the other. Intermediate forms were wholly wanting, so that the conjecture that it either must be an abnormal growth of that species, or a new variety is wide of the mark."

Flowering from late May to early October, and soon ripening fruit.

"Shallow shaded rivulets," through Piedmont Region above the Fall-line, western Connecticut to Northeastern Pennsylvania; reported by Porter from Franklin County, Pennsylvania, and seen from Keweenaw County, Michigan, collected July 8 , I9I 5 by $O$. A. Farwell 4005 .

Connecticut.* Litchfield: North Canaan, E. B. Harger $6238(\mathrm{~A})$.

New York. Greene: New Baltimore, N. Taylor I289 (Y). Queens: Flushing, J.A. Bisky (E, Y); Jamaica (Y). Rockland: Spring Valley (Y); Tappan, W. H. Leggett (Y).

New Jersey. Bergen: Carlstadt (Y); Carlton Hill, G. $V$. Nash 244 (Y); Mahwah (Y). Hunterdon: banks of Delaware River above Stockton, C. S. Williamson (A). Passaic: Passaic, E. W. Berry (Y). (P) Warren: Flatbrookville, (A); Manunka Chunk, Phillipsburg, T. C. Porter (A, Y).

Pennsylvania. Northampton: Pot Rock, etc., near Easton, T. C. Porter (A, P, Y); Johnsonville (A); Martins Creek (A); Riverton (A).

\section{Veronica glanđifera Pennell sp. nov.}

Flowering stem 3-9 $\mathrm{dm}$. long, glabrous or distally glandularpubescent. Leaves lanceolate, acuminate, more or less serrate,

* Localities for specimens seen are grouped by counties, and these listed in alphabetic sequence.

Herbaria cited: A. Academy of Natural Sciences, Philadelphia.

E. Brooklyn Botanic Garden, Brooklyn.

P. University of Pennsylvania, Philadelphia.

Y. New York Botanical Garden, New York. 
7-10 $\mathrm{cm}$. long, I.2-2.5 $\mathrm{cm}$. wide, all clasping, the lowest submersed ones elongated. Racemes axillary to the upper leaves, ro-20 cm. long, 30-60 flowered. Bracts narrowly lanceolate, $4^{-6} \mathrm{~mm}$. long. Pedicels $3^{-6} \mathrm{~mm}$. long, glandular-pubescent with scattered hairs. Sepals 3-4 $\mathrm{mm}$. long, lanceolate, acute to acuminate. Corolla about $3 \mathrm{~mm}$. long, not seen fresh. Capsule $2.5-3 \mathrm{~mm}$. long, 3-3.5 mm. broad, broad-globose, emarginate. Seeds $+\mathrm{mm}$. long, oval, yellow-brown.

Type, vicinity of Suffolk, Nansemond County, Virginia, collected in flower and fruit May 27, 1893. N. L. Britton and $J$. K. Small: in herbarium Columbia University at the New York Botanical Garden.

Flowering from late May to late July, and soon ripening fruit.

Shallow flowing streams, mainly in calcareous soil, through the lower Piedmont from the Delaware valley southwestward.* Ranges from New Jersey to North Carolina, Minnesota and Kentucky.

New Jersey. Warren: Warrenville, C. S. Williamson (P).

Pennsylvania. Bucks: Rockhill, A. MacElwee (A); Sellersville (A). Chester: West Chester, W. Darlington (A, Y). Lancaster: Dillerville Swamp, J. K. Small (Y). Montgomery: Conshohocken (A); Manayunk, Shannonville J. Crawford (A) Philadelphia: East Park (P) I. C. Martindale (A). Wayne Junction (A).

15. Veronica scutellata L., Sp. Pl. I2. I753. "Habitat in Europae inundatis."

Flowering from late May to September, and soon ripening fruit.

Swales and along streams, through the area above the Fallline, becoming common northward. Ranges from Newfoundland to Yukon, south to Virginia, Wyoming and California; also through Eurasia.

* In the herbarium of the Charleston Museum, Charleston, South Carolina, is a sheet of glandifera bearing the inscription "Marl indicator!! Va. M. T." Dr. Barnhart identifies this comment as that of Michael Tuomey, a teacher in Virginia, who afterward became State Geologist of South Carolina, My only finding of this plant has been on limestone at Natural Bridge, Virginia, Pennell 9802 . 
[Reprinted from Torreya, Vol. 19, No. II, November, 1919.]

\title{
SCROPHULARIACEAE OF THE LOCAL FLORA. IV
}

\author{
By Francis W. PEnNell
}

\author{
13. Aureolaria Raf. New Fl. Amer، 2: 58 . 1837 \\ Type species, A. villosa Raf.
}

Annual. Stem, leaves and calyx with stalked or sessile glands. Leaves bipinnatifid, more or less pectinately cut. Calyx-lobes dentate to pectinate. Corolla externally glandular-pubescent, within pubescent over bases of the posterior lobes; more or less marked or tinged with purple-red. Anther-sacs 2.5-4 mm. long. Capsule ellipsoid, 9-12 $\mathrm{mm}$. long, $\mathrm{r} / 2-2 / 3$ enclosed in the calyx-tube, glandular-puberulent. Seeds $.8 \mathrm{~mm}$. long, not winged. Pedicels Io-28 mm. long. (Panctenis Raf.)

Stem closely pubescent above, not or scarcely glandular. Leaves puberulent, not or slightly glandular. Capsule narrowly ellipsoid, 9-II mm. long.

Leaves $3-6 \mathrm{~cm}$. long. Pedicels mostly shorter than to equaling the bracts. Stem (frequently) glandular-hirsute below.

I. A. pedicularia.

Leaves $1.5^{-2.5} \mathrm{~cm}$. long. Pedicels longer than the bracts. Stem not glandularhirsute below.

Ia. A. pedicularia caesariensis.

Stem glandular-pubescent above with scattered glands. Leaves glandular-puberulent to pubescent. Capsule ellipsoid, I I-I $2 \mathrm{~mm}$. long.

Ib. A. pedicularia intercedens.

Perennials. Not glandular. Leaves entire to pinnately cut, and slightly bipinnatifid, though not pectinate. Corolla externally glabrous, within glabrous or diffused-pubescent; not marked or tinged with red-purple. Anther-sacs 4-6 mm. long. Capsule ovate to globose-ovate in outline, not enclosed within the calyx-tube, not glandular. Seeds $1.5^{-2.7} \mathrm{~mm}$. long, broadly winged. 
Pedicels I.5-Io (-I5) mm. long. (Euaureolaria.)

Capsule densely rusty-pubescent. Stem pubescent and leaves downy-pubescent. Pedicels $x \cdot 5-3 \mathrm{~mm}$. long.

Capsule glabrous. Stem glabrous and leaves glabrous or minutely puberulent on the upper surface. Pedicels $3 \mathrm{~mm}$. long or longer.

Stem slender, not glaucous, rarely purplish. Petioles very short, less than to $\mathrm{mm}$. long. Lower leaves lanceolate to ovate-lanceolate, widest below the middle, long-acuminate. Pedicels 3-8 $\mathrm{mm}$. long. Corolla $30-35 \mathrm{~mm}$. long. Seeds $1.5^{-1.7} \mathrm{~mm}$. Iong.

Stem relatively stout, glaucous, frequently purple. Petioles mostly over Io $\mathrm{mm}$. long. Lower leaves ovate-Ianceolate to ovate, widest about the middle, not long-acuminate. Pedicels 5-Io (-I 5) $\mathrm{mm}$. long. Corolla $35^{-40} \mathrm{~mm}$. long. Seeds $2-2.7 \mathrm{~mm}$. long.

2. A. virginica.

3. A. laevigata.

4. A. flara.

I. Aureolaria pedicularia (L.) Raf.

Gerardia pedicularia L. Sp. Pl. 6I I. I753. "Habitat in Virginia, Canada." Type not seen, but description sufficiently distinctive.

Panctenis pedicularia (L.) Raf. New Fl. Amer. 2: 6I. I837. The specific name spelled by Rafinesque "pedicularis." Aureolaria pedicularia (L.) Raf. l.c. 6I. I837.

Dasystoma pedicularia (L.) Benth. in DC. Prod. I0: 52I. I 846.

Agalinis pedicularia (L.) Blake in Rhodora 20: 70. I9I8.

Flowering from early August to late September, fruiting from September into November.

Dry oak-woodland, thin soil, sandy or rocky, occasional or local above Fall-line, more frequent southwestward; in the Coastal Plain of Long Island and New Jersey, passing into var. caesariensis. Northwestward the species passes into var. intercedens. Ranges, southward and westward mainly through its varieties, from western Maine to North Carolina and Minnesota. 
Ia. Aureolaria pedicularia Caesariensis Pennell in Bull. Torrey Club 40: 4I3. I9I3. "Type, Atco, Camden Co., New Jersey, Sept. 7, I9I I, F. W. Pennell 3545 in Herb. University of Pennsylvania."

Sandy open woodland, Coastal Plain of Long Island and New Jersey, mainly in the Pine Barrens, where it replaces the species. Occurs northeastward to southeastern Massachusetts.

I $b$. Aureolaria pedicularia intercedens Pennell, var. nov.

Stem glandular-pubescent above, with spreading or recurved short hairs, scattered among which occur glands which are borne on stalks shorter than or longer than the pubescence. Leaves somewhat puberulent with short-stalked glands. Calyxlobes $8-\mathrm{I} 3 \mathrm{~mm}$. long. Capsule II-I $2 \mathrm{~mm}$. long. Otherwise as in the species.

Type, Mt. Arlington, Morris Co., New Jersey, collected in flower August 26, I906, K. K. Mackenzie 2356; in Herb. Missouri Botanical Garden.

Environment of the species, between which and the densely hirsute western A. pedicularia ambigens (Fernald) Farwell it forms a connected series of intergradations. Occasional in northern New Jersey and eastern Pennsylvania, to be expected with the species in our northwestern counties in New York.

2. Aureolaria virginica (L.) Pennell.

Rhinanthus virginicus L. Sp. Pl. 603. I753. "Habitat in Virginia." As specimen in the Linnean Herbarium bears the handwriting of Linné the younger and so appears to have been a late addition, Gronovius's plant must be taken as the type. This is Clayton 488, recently identified by Dr. S. F. Blake, in Rhodora 20:66. I9I8, as the plant here considered. Our traditional applications of the names virginica and flava must be transposed.

Aureolaria villosa Raf. New Fl. Amer. 2: 59. I837. No type locality given, nor type known to exist. Description sufficiently distinctive.

Dasystoma pubescens Benth. in DC. Prod. I0: 520. I846. "In Americae sept. civitatibus orientalibus frequens." Type not verified, but description sufficiently distinctive. 
Gerardia sirginica (L.) Britton in Prelim. Cat. N. J. Pl. 40. I 888 .

Dasystoma virginica (L.) Britton in Mem. Torr. Bot. Club 5: 295. 1894.

A ureolaria virginica (L.) Pennell in Bull. Torr. Bot. Club 40: f09. I9I3.

A galinis virginica (L.) Blake in Rhodora 20: 7I. I9I8.

Flowering from early July to mid-August, fruiting from August to October.

Dry open oak-woods, usually sand or a sandy loam, frequent or common throughout our area, less general within the Pine Barrens. Ranges from New. Hampshire to Florida, west to Michigan, Kentucky and Louisiana.

3. Aureolaria laevigata (Raf.) Raf.

Gerardia levigata Raf. Ann. Nat. I3. I820. "It grows on the knob hills of Kentucky, the Cumberland mountains and the Alleghany." No type known to exist, unless it be a specimen in Herb. New York Botanical Garden, labeled in Rafinesque's handwriting, "Gerardia-n. sp.Kentucky."

Aureolaria levigata (Raf.) Raf. New Fl. Amer. 2: 59. 1837. Dasystoma laevigata (Raf.) Chapm. Fl. S. Un. St. ed. II: 636. I 883 .

Agalinis laevigata (Raf.) Blake in Rhodora 20: 7I. I9I8.

Oak-woodland, usually rocky, along streams or on mountainsides along the Susquehanna River in Lancaster Co., Pennsylvania. Ranges through the Appalachians from central Pennsylvania to South Carolina and Tennessee.

4. Aureolaria flava (L.) Farwell.

Gerardia flava L. Sp. Pl. 6ro. I753. "Habitat in Virginia, Canada." Specimen in Linnean Herbarium identified by Bentham; see in Comp. Bot. Mag. I: I98. I836.

Gerardia glauca Eddy in Med. Repos. N. Y., IInd Hex. 5: 126. I807. Plandome, Long Island. C. W. Eddy. Type not seen nor known to exist, but description quite distinctive. 
Gerardia quercifolia Pursh, Fl. Amer. Sept. 423. I8I4. "On the banks of rivers, in rich shady places, Pensylvania to Carolina." Type not seen, but description distinctive.

A ureolaria glauca (Eddy) Raf. New Fl. Amer. 2: 60. 1837. Dasystoma quercifolia (Pursh) Benth. in DC. Prod. I0: 520. I8+6.

Dasystoma flava (L.) Wood, Class-Book 529. I86I. As to synonymy, not description, the latter applying to Aureolaria virginica.

Agalinis glauca (Eddy) Blake in Rhodora 20: 7I. I9I8.

Aureolaria flava (L.) Farwell in Rep. Mich. Acad. Sci. 20: I88. I9I8.

Flowering from late August to late September, fruiting from September to November.

Dry to rather moist oak-woodland, usually on rocky hillsides, loam or sometimes in sandy soil, frequent or locally common through the counties above the Fall-line, especially toward the mountains; on northern Long Island, but rare in southern Long Island and very rare in the Coastal Plain of New Jersey. Including varieties, this species ranges from Maine to Florida, Illinois, Arkansas and Louisiana.

\section{I4. Agalisis Raf. New Fl. Amer. 2:61. I837 \\ Type species, $A$. palustris Raf.}

Corolla with lobes all spreading, pubescent within at base of posterior lobes.

Seeds dark-brown. Plants tending to blacken in drying. Calyx-tube not evidently reticulate-venose.

Pedicels less than $\mathrm{I} 2 \mathrm{~mm}$. long. Inflorescence of normal racemes. Seedcoat with dark-brown ridges, between which are broad areas, paler and minutely reticulate.

Leaves and calyx-lobes obtuse to acutish. Anthersacs obtuse to acutish. Plant fleshy, bushybranched below, with elongated racemes above. Pedicels $5^{-12} \mathrm{~mm}$. long. Corolla $\mathrm{I} 2-\mathrm{I} 7 \mathrm{~mm}$. long.

I. A. maritima.

Leaves and calyx-lobes acute to acuminate. Anthersacs mucronate to minutely awned. Plants not fleshy, more uniformly branched. Pedicels rarely over $5 \mathrm{~mm}$. long. 
Calyx-lobes $4 / 5-7 / 8$ the length of the tube, triangular-lanceolate to lanceolate. Corolla I 2-2O (-23) mm. long. Stem $1-6 \mathrm{dm}$. tall. Anther-sacs somewhat pubescent to glabrous.

2. A. paupercula.

Calyx-lobes $I / 6-I / 2$ the length of the tube, triangular-lanceolate to subulate. Corolla $20-$ $38 \mathrm{~mm}$. long. Stem 3-I2 dm. tall. Anther-sacs densely lanate.

Stem relatively stiffly branched, sparingly scabrellous. Calyx-lobes triangular-lanceolate to subulate. Corolla $20-38 \mathrm{~mm}$. long. Leaves linear, $\mathrm{I}-3 \mathrm{~mm}$. wide.

3. A. purpurea.

Stem slender, virgately branched, glabrous. Calyx-lobes triangular-subulate to subulate. Corolla 20-25 mm. long. Leaves narrowly linear to almost filiform, .5-1 mm. wide.

Pedicels I 5 $^{-40} \mathrm{~mm}$. long. Inflorescence a short raceme, 4. A. virgata. one pedicel (by arrested growth of the rhachis) appearing terminal. Seed-coat with dark-brown ridges, between which are narrow scarcely paler. areas. Corolla $\mathrm{I} 8-25 \mathrm{~mm}$. long. Leaves narrowly linear to filiform.

5. A. Holmiana.

Seeds yellowish-brown. Plants scarcely tending to bla ken in drying. Calyx-tube evidently reticulate-venose. Corolla I3-I $5 \mathrm{~mm}$. long.

Calyx-tube campanulate, $3 \mathrm{~mm}$. long, firmer in texture, $2 / 3^{-3} / 4$ the length of the capsule, its lobes $.5^{-1} \mathrm{~mm}$. long, triangular-acuminate, not or scarcely callose. Seeds .4-.6 mm. long, strongly reticulate. Pedicels mostly $\mathrm{I}-2$ times the length of the bracts. Stem usually I-4 dm. tall.

6. A. acuta.

Calyx-tube hemispheric, $2.5-3 \mathrm{~mm}$. long, thinner in texture, $3 / 5^{-2} / 3$ the length of the capsule, its lobes minute, .05-.2 (-.3) mm. long, strongly callose. Seeds $.6-.8 \mathrm{~mm}$. long, obscurely reticulate. Pedicels mostly 2-3 times the length of the bracts. Stem usually $2-5$ dm. tall.

7. A. decemloba.

Corolla with the posterior lobes ascending-arched over the stamens and style, glabrous within at base of the posterior lobes. Racemes elongated, normal. Pedicels $12-27 \mathrm{~mm}$. long. Seeds dark-brown.

8. A. tenuifolia.

I. Agalinis maritima (Raf.) Raf.

Gerardia maritima Raf. in Med. Repos. N. Y., IInd Hex. 5: 36r. I808. "Found in the islands of Egg-Harbour, in New Jersey." No type known to exist, but description 
quite distinctive. An unpublished plate of Rafinesque's is in the library of the New York Botanical Garden.

Gerardia purpurea crassifolia Pursh, Fl. Amer. Sept. 422. I8I4. "In salt marshes, near New York." Type not seen, but description sufficiently distinctive.

Agalinis maritima (Raf.) Raf. New Fl. Amer. 2: 62. 1837.

Flowering from mid-July to early September, fruiting September to October.

Salt marshes, along the Atlantic coast, Connecticut, New York and New Jersey. If separable from the much larger plant of the Southern and Gulf coast, our species ranges from Virginia northward to Maine, becoming progressively smaller and simpler northward.

2. Agalinis paupercula (A. Gray) Britton.

Gerardia purpurea paupercula A. Gray, Syn. Fl. N. Amer. II. I: 293. I878. "Lower Canada to Saskatchewan and southward from coast of New England to Penn., N. Illinois and Wisconsin." Numerous specimens labeled by Gray seen, but none indicated as typical. In synonymy is mentioned the name intermedia Porter in herb., so selecting a type.

Gerardia paupercula (A. Gray) Britton in Mem. Torr. Bot. Club 5: 295. I894.

Agalinis paupercula (A. Gray) Britton in Britton \& Brown, Ill. Fl. ed. II. 3: 210. I9I3.

Flowering from early August to September, fruiting September to October.

Moist soil, borders of lakes and in bogs, especially where sandy, in the glaciated region; through the area east of the Hudson River, occasional in Connecticut and northward in New York, very rare southward and on Long Island only at Lake Ronkonkoma; near Dingmans Ferry, Sussex Co., New Jersey (W. M. Van Sickle (E)), and doubtless occasional elsewhere in the glaciated region west of the Hudson, especially in New York. Ranges through glacial bog country from New Brunswick to Minnesota, but seems to be much more common in northern New England and in Michigan than through the intervening 
area. Along their lines of contact in southern New England, our area and in northern Indiana and Illinois, this intergrades somewhat with its obvious parent, $A$. purpurea.

3. Agalinis plirpurea (L.) Pennell.

Gerardia purpurea L. Sp. P1. 6I0. 1753. "Habitat in Virginia, Canada." The Linnean diagnosis includes both long and short-pediceled plants, so could include all pink (="purple") flowered species. The first citation accompanied by a figure, Plukenet's "Digitalis virginiana rubra, foliis \& facie Antirrhini vulgaris," evidently the prevalent plant of the Atlantic seaboard now under consideration, is counted as the type.

Gerardia purpurea grandiflora Benth. in Comp. Bot. Mag. I: 208. I 836. "Hab. New Jersey." Type, labeled "New Jersey, Torrey I 834," seen in Kew Herbarium.

Agalinis palustris Raf. New F1. Amer. 2:62. I837. "Near marshes ... From New England to Carolina." Type not known to exist. Evidently intended for the prevalent plant of the Atlantic seaboard.

Agalinis longifolia Raf. 1.c. 62. 1837 . "Near streams New Jersey to Virginia." Type not known to exist. A smaller form.

Gerardia purpurea f. albiflora Britton in Bull. Torr. Bot. Club 17: 125. I890. New Jersey. An albino state. Plants with pure white corollas are occasional in any species of this genus.

Gerardia purpurea parvula Pennell in Proc. Acad. Nat. Sci. Phila. 62: 572. I9II. "Serpentine, Wawa, Delaware county, Penna., F. IV. Pennell 2689, coll. Sept. 25, I9I0, in Herb. Acad. Nat. Sci. of Phila." The smallerflowered depauperate plant characteristic of the Serpentine Barrens.

Agalinis purpurea (L.) Pennell in Bull. Torr. Bot. Club 40: I26. 1913 .

Aureolaria purpurea (L.) Farwell in Rep. Mich. Acad. Sci. 20: $189 . \quad 1918$.

Flowering from late August to mid-September, fruiting September to October. 
Moist sandy soil, edges of salt-marsh, of lakes, or of rivers, in depressions among sand-dunes, or locally on barren magnesian loam in the Serpentine; abundant through the Coastal Plain of New Jersey and common in southern Long Island, in the PineBarrens replaced by $A$. virgata; above the Fall-line occasional near ponds and bogs of northern New Jersey, in the bogs of Lancaster Co., Pennsylvania, and in meadows and on dry grassy upland of the Serpentine Barrens of Delaware and Chester counties, Pennsylvania. Ranges from Massachusetts to Florida, Minnesota and Texas, mainly in the Coastal Plain or at low elevations inland.

4. Agalinis virgata Raf. New Fl. Amer. 2: 62. I837. "Glades of Pine woods in South New Jersey near Mullica Hill, \&c." Type not known to exist.

Gerardia racemulosa Pennell in Torreya II: I5. I9II. "Type-Parkdale, Camden Co., N. J., F. W. Pennell 2692 Coll. Sept. 27, I9Io, in Herb. Acad. Nat. Sci. of Phila."

Flowering from September to mid-October, fruiting slightly later.

Moist sandy pine-barrens, or occasionally in open sand, in the Pine Barrens of Long Island (Great River, Suffolk Co., E. $P$. Bicknell) and of southern New Jersey. Ranges from Long Island to South Carolina, in the pine barrens of the Coastal Plain. An obvious derivative of $A$. purpurea.

5. Agalinis Holmana (Greene) Pennell.

Gerardia Holmiana Greene, Pittonia 4: 52. I 899. "Plentiful in open pine and oak groves along Michigan Avenue south of the Soldiers' Home grounds near Brookland, D. C., collected by Mr. Holm and the writer, 2o Oct., I898." No specimen of this date seen, but one in the herbarium of the New York Botanical Garden, of Dr. Greene's collecting, from Brookland, D. C., dated Oct. I6, I898, may stand as the type. I have collected this plant at the type station.

Agalinis Holmiana (Greene) Pennell in Bull. Torr. Bot. Club 40: 429. I9I3. 
Flowering early September to mid-October, fruiting slightly later.

Dry sandy pine-land, in the Coastal Plain. Occasional on Long Island, and common through the Pine Barrens of southern New Jersey. Ranges from Long Island to Alabama, through the Coastal Plain.

6. Agalinis acuta Pennell in Bull. Torr. Bot. Club 42: 338. I915. "Type: dry sandy downs, Edgartown, Martha's Vineyard, Massachusetts, collected in flower September I2, I901, M. L. Fernald $45^{\circ}$ in United States National Herbarium."

Flowering from late August to mid-September, fruiting September to October.

Dry sandy soil, sterile sandy loam, local in the Coastal Plain of Long Island, and known inland from Farmington, Hartford Co., Connecticut (Bissell 14, 48, 439). Abundant on the Hempstead Plains of Long Is!and, one of the most distinctive plants of that prairie.

7. Agalinis decenloba (Greene) Pennell.

Gerardia decemloba Greene, Pittonia 4: 5I. I899. "Plant not uncommon about Brookland, D. C., inhabiting grassy knolls and hillsides bordering on pine woods." A specimen in herb. New York Botanical Garden, collected by Dr. E. L. Greene at Brookland, D. C. in Oct., I898, may stand as the type.

Agalinis decemloba (Greene) Pennell in Bull. Torr. Bot. Club 40: 434. I913.

Flowering from early September into October, fruiting late September an October.

Dry soil, sand or clay, in our area only in southern Lancaster Co., Pennsylvania. (New Texas and Wakefield.) Ranges from thence southwestward to northern Alabama, but with a distribution much broken, though, like the last, locally common.

8. Agalinis tenuffolia (Vahl) Raf.

Gerardia tenuifolia Vahl, Symb. Bot. 3: 7. I794. "Habitat in America septentrionali." Type in Herb. Universi- 
tetets Botaniske Museum, Copenhagen, Denmark, collected by Von Rohren, and said to be probably from Philadelphia, is identified by Dr. C. H. Ostenfeld as identical with my number $268 \mathrm{I}$ from Secane, Delaware Co., Pennsylvania.

Agalinis tenuifolia (Vahl) Raf. New Fl. Amer. 2: 64. $\quad$ I837. Gerardia tenuifolia f. albiflora Britton in Bull. Torr. Bot.

Club I7: 125. I890. "Found by Mr. Leggett at South Amboy, and by Mr. Schuh at Rosemont, [New Jersey]." An albino state.

Aureolaria tenuifolia (Vahl) Farwell in Rep. Mich. Acad. Sci. 20: 189. I918.

Aureolaria tenuifolia albiflora (Britton) Farwell, 1.c. I90. I9I 8.

Flowering from late August to early October, fruiting September and October.

Dry loam, or at times sandy soil, usually in open deciduous woodland, common throughout the area above the Fall-line; on northern Long Island; in the Coastal Plain of Long Island and New Jersey occasional, or frequent in heavy soils, not in the Pine Barrens. Ranges from Maine to Georgia, Louisiana, Michigan and Missouri, and in its varieties westward to North Dakota, Colorado and Texas.

\section{I5. Отоphylla Benth. in DC. Prod. I0: 5 I2. I 846}

Type species, Gerardia auriculata Michx.

(?) Tomanthera Raf., New Fl. Amer. 2: 65. I837. Type species, T. lanceolata Raf.

I. Otophylla auriculata (Michx.) Small.

Gerardia auriculata Michx. Fl. Bor. Amer. 2: 20. 1803. "In pratis regionis Illinoensis." Type not verified, but description sufficiently distinctive.

Seymeria auriculata (Michx.) Spreng. Syst. 2: 8Io. I825.

(?) Tomanthera lanceolata Raf. New Fl. Amer. 2:66. 1837. "My specimen of Collins' herbarium was collected by Dr. Cleaver in New Jersey." The description of this is erroneous for our plant in describing the anther-sacs as 
unequal; actually they are alike in each stamen but those of the posterior stamens are smaller. However I am convinced that ours must be the plant of Rafinesque, and that such an error is due either to a lapse of memory in recording his observation or more likely to confusing in his dried specimen the sacs of two different stamens. This opinion is confirmed by Rafinesque's inclusion in his new genus of Michaux's plant. However for any thing less than a certainty and for an untrue name it may be unwise to dispossess Bentham's well-chosen name.

Tomanthera auriculata (Michx.) Raf. 1. c. 66. I 837.

Otophylla Michauxii Benth. in DC. Prod. Io: 512. I8+6. New name for Gerardia auriculata Michx.

Otophylla auriculata (Michx.) Small, Fl. S.E. Un. St. I075, I338. 1903.

Agalinis auriculata (Michx.) Blake in Rhodora 20: $7 \mathrm{I}$. I9I 8.

Aureolaria auriculata (Michx.) Farwell in Rep. Mich. Acad. Sci. 20: 189. 1918.

Flowering from late August to mid-September, fruiting September and October.

Old fields and railway banks, occasional in New Jersey and Pennsylvania. Certainly introduced from the prairies of the Mississippi Valley states. 


\section{SCROPHULARIACEAE OF THE LOCAL FLORA. V}

By Francis W. Pennell

\section{Concluded from November TORREYA}

\section{I6. Buchnera L. Sp. Pl. 630. I753 \\ Type species, B. americana $\mathrm{L}$.}

I. Buchnera AMericana L. 1.c. 630. I753. "Habitat in Virginia, Canada." Based. upon Gron., Fl. Virg. 74. I743, typified by Clayton 142 from Virginia. Type not verified, but description distinctive.

Flowering in July, fruiting in August and September.

Sandy or sterile loam soil, occasional in the Piedmont Region in the southwestern extremity of our area. Delaware County, Pennsylvania (Williamson School), Lancaster Co. (Pleasant Grove), and in Newcastle Co., Delaware (Centreville). Ranges from Pennsylvania to Florida, southern Ontario, Illinois and Louisiana.

I7. Schwalbea L. Sp. Pl. 6o6. 1753

Type species, S. americana L.

I. Schivalbea americana L. 1.c. 606. I753. "Habitat in America septentrionali." "Linné had in his herbarium no specimen of this, so that his species is based wholly upon Gron., Fl. Virg. 7I. I743, typified by Clayton 33 from from Virginia. This from the description of the leaves as lanceolate and the plant as quite pubescent would appear to have been the species now considered.

Flowering from mid-June to early July, fruiting in September. Sandy soil, usually rather damp, in pineland and about edges of salt-marsh, in the Coastal Plain of southern New Jersey and 
in central Delaware. Ranges from southeastern Massachusetts to Virginia, so is to be expected in eastern Long Island.

\section{i 8. Castilleja Mutis; L. f. Suppl. 293. I78I}

Type species, C. fissifolia L. f., of Colombia

I. Castilleja coccinea (L.) Spreng.

Bartsia coccinea L. Sp. Pl. 602. I753. "Habitat in Virginia, Noveboraco . . . Hort. Cliff. 235." From L., Hort. Cliff. 325. 1737, "Crescit in Virginia, unde delatam communicavit DD. Gronovius," and from Gron., Fl. Virg. 69. I743, "Clayt. n. 293." Clayton 293, the type, must be certainly the species here considered. Rhinanthus coccineus (L.) Lam. Encyc. 2: 60. 1786.

Euchroma coccinea (L.) Nutt. Gen. N. Am. Pl. 2: 55. 1818. Type of the genus Euchroma Nutt.

Castilleja coccinea (L.) Spreng. Syst. 2: 775. 1825 .

Flowering from late April to early June, and soon ripening fruit.

Meadows and moist grassy slopes, loam or sandy loam, through the Piedmont Region, more frequent westward; in the Coastal Plain occasional in the Middle District of southern New Jersey. Ranges from Maine to Manitoba south to South Carolina and Kansas.

19. Rhinanthus L. Sp. P1. 603. 1753

Type species, R. Crista-galli L., of Europe

\section{Rhinanthus Crista-galli L.}

Flowering in May and early June, fruiting in late June.

Fields and open places near Stratford, Connecticut. Probably introduced from Eurasia, although said to be native northeastward.

20. Pedicularis L. Sp. Pl. 607. 1753

Type species, $P$. palustris L., of Europe

Stem 6-8 dm. tall, glabrous. Leaves shallowly lobed, the sinuses narrow, the lobes with minute regular crenations. Bracts auriculate near base. Rachis of inflorescence glabrous. Fused sepals of each side terminating in a slightly enlarged crenate foliar tip, glabrous or with a very few long hairs near base. Corolla with truncate apex of posterior 
lobes without tooth-like processes. Capsule brown, scarcely exceeding calyx, slenderly beaked. Flowering in late summer.

I. P. lanceolata.

Stem I-3 dm. tall, hirsute, especially above. Leaves deeply lobed, the sinuses broad, the lobes with more prominent irregular crenations. Bracts entire near base. Rachis of inflorescence lanate. Fused sepals of each side broadly acute, entire, pubescent along the veins. Corolla with apex of posterior lobes each with a tooth-like process. Capsule straw-colored, twice as long as the calyx, scarcely beaked. Flowering in spring.

2. P. canadensis.

i. Pedicularis lanceolata Michx. Fl. Bor. Am. 2: i8. i803. "Hab. in regione Illinoensi [A. Michaux]." Type not verified, but description distinctive.

Pedicularis auriculata Sm. in Rees Cycl. 26: I8I3. "Sent by the Rev. Dr. Muhlenberg, from the neighborhood of Lancaster in Pennsylvania." Description distinctive.

Pedicularis pallida Banks; Pursh, Fl. Am. Sept. 424. I8I4. "In a swamp near Kings-bridge, New York. . . . Ph. [= Pursh] . . . v.v.; v.s. in Herb. Banks." Description distinctive.

Flowering from late August to late September, fruiting late September and October.

Swales and moist meadows, loam soil, in the Piedmont region, more frequent southwestward; occasional in the Middle District of the Coastal Plain of southern New Jersey, extending nearly to Cape May. Ranges from Massachusetts to Manitoba, North Carolina and Nebraska.

2. Pedicularis canadensis L. Mant. 86. i 767 . "Habitat in America septentrionali. Kalm." Description distinctive. Pedicularis gladiata Michx. Fl. Bor. Amer. 2: I8. 1803. "Hab. in Pennsylvania [A. Michaux]." Description quite distinctive.

Flowering from late April to late May, fruiting in late May and early June.

Woodland, or on knolls in meadows, loam or sandy loam, common throughout above the Fall-Line; in the Coastal Plain frequent or occasional in Long Island and in the Middle District of southern New Jersey. Ranges from Nova Scotia to Manitoba, south to Florida and Texas. 
21. Melampyrum L., Sp. Pl. 605. I 753

Type species, $M$. cristatum L. of Europe

Main stem-leaves linear or lanceolate-linear. Bracts conspicuously fimbriate near base, with teeth frequently as long as the width of the blade. Capsules mostly 6-7 $\mathrm{mm}$. long, curved and usually attenuatebeaked. Seeds $2-2.5 \mathrm{~mm}$. long, brown to blackish. Main stem-leaves linear-lanceolate to nearly ovate. r. M. lineare. Bracts slightly or not fimbriate near base, the teeth shorter than the width of the blade. Capsules frequently larger, reaching 8-9 $\mathrm{mm}$. long, slightly or not curved and less or not attenuate-beaked. Seeds often larger, reaching $3 \mathrm{~mm}$. long, usually black.

Ia. M. lineare latifolium.

I. Melampyrum lineare Desr.; Lam. Encyc. 4: 22.1796. "Rapportée de la Caroline par M. Fraser ... (v.s.)" Description made from a very small and young plant, but certainly of the form here considered. Characterization of calyx as 5 -toothed surely erroneous.

Flowering from mid-June to September, and soon ripening fruit.

Sandy soil, pineland and in open deciduous woodland, common throughout the Coastal Plain; inland occasional and mostly transitional to var. latifolium. Ranges from Massachusetts to North Carolina, and, including varieties, inland northward across the continent.

i $a$. Melampyrum lineare latifolium (Muhl.) Beauverd

Melampyrum americanum Michx. Fl. Bor. Amer. 2: I6. I 803. "Hab. a sinu Hudsonis ad montosam Carolinam. [A. Michaux.," Description evidently of the prevalent inland broader-leaved plant.

Melampyrum latifolium Muhl. [Cat. 57. I8I3. nomen nudum]; Eaton, Man. Bot. N. \& M. St. ed. II 3I6. I818. From Muhlenberg's Catalog, the type station is in Delaware. Type not seen, but evidently is of the inland broader-leaved plant.

Melampyrum americanum latifolium (Muhl.) Eaton, 1.c. ed. III. $350 . \quad 1822$.

Melampyrum pratense americanum (Michx.) Benth. in DC. Prod. 10: $5^{84}$. 1846 . 
Melampyrum lineare latifolium (Muhl.) Beauverd in Mem. Soc. Phys. Genève 38: 474 . I916.

Melampyrum lineare americanum (Michx.) Beauverd, 1.c. 476. 1916. Beauverd distinguishes latifolium with bracts broader, the lower entire, the upper entire or few-toothed, and the first flower placed at the third or fourth node, from americanum with bracts narrower, the lower entire or slightly toothed, the upper always toothed, and the first flower in the axil of the fourth to eighth node. His americanum is transitional from latifolium to lineare itself, from which he distinguishes both these varieties as having corolla whitish, tinged with purple, instead of pale-yellow, tinged with purple. The corolla of the species, as well of var. latifolium as I understand it, has the corolla white, posteriorly more or less tinged with red, especially in age, and only the palate yellow. His color distinction cannot be maintained, and I should consider the broadest, most entire-leaved plants as an extreme of this variety.

Flowering from late May to mid-August, and soon ripening fruit.

Dry open woods, in potassic soil, sandy or sterile, locally common on sandstone or shale ridges, etc., throughout the area above the Fall-line; in the Coastal Plain occasional on Long Island and in the Middle District of southern New Jersey. Intergrading to the species.

\section{Local Specimens of the Author's Collecting}

As my own collections illustrating our local species of Scrophulariaceae in part have already been, and in part are soon to be, distributed to various herbaria, it may be well here to present a summary of the numbers of these. The specimen numbers will be grouped by species and states. All are from the local flora as defined in the introduction to these studies.

Agalinis acuta (N. Y.) 5292, 6551, 6552, 9340, 10126.

Agalinis Holmiana (N. Y.) ror67. (N. J.) r662, 2695, 3544, $35^{8} 3,3628,6483,9117$. 
Agalinis maritima (N. Y.) 9359. (N. J.) 1807, 2157.

A galinis purpurea (N. Y.) 529I, 6549, 6647, 9366, IoI 46 . (N. J.) $2602,2603,2604,4004,6492,6524,6637,9294$. (Pa.) $476,750,786,838,847$, I660, 2682, 2689, 3598, 3609, 5182, 5272,8984 .

Agalinis tenuifolia (Conn.) 8578. (N. Y.) 665I, 6698, 9226. (N. J.) $1664,6534,9870$. (Ра.) 658, 837, I642, 268 I, 2688, 2690, 3543, 5289, 8906 .

Agalinis virgata (N. J.) 2692, 2694, 3584, 3626, 3808, 652I, 6523 , 9II 4.

Aureolaria flava (N. Y.) 5293, 8434, 9407. (N. J.) 8358 . (Pa.) $35+\mathrm{I}, 3624,5225,5260,5284,5286,679 \mathrm{I}$.

Aureolaria pedicularia (N. Y.) 9225, гог7I. (N. J.) 10040. (Pa.) 583, 99I, I948, 3542, 3559, 3585, 3589, 3625, 5192, 5226, 526I, 5262, 5265, 5288, 883I, 8860. (Del.) I5I9. (Md.) I6I9.

Aureolaria pedicularia caesariensis (N. J.) $1837,35+5,3627$, 6487,9 I 55.

Aureolaria pedicularia intercedens (Pa.) 676, 4982.

A ureolaria virginica (N. Y.) 5294, 6868, 8459. (N. J.) 3546, $3986,6489,7363,7+28,8345,9208$. (Рa.) 337, 4985, 502I, $5067,5227,5259,5283,6503,6793,7850,7912,8847,9412$. (Del.) 7754. (Md.) 1615.

Castilleja coccinea (Pa.) I290, 2034, 2772.

Chelone glabra (N. Y.) 6643, 6678, 6745, 6833, 6898, 8604, 9239, 9308, 9397, 9400. (N. J.) 6485, 6525, 6543, 9223, 9224. (Pa.) 6794 .

Chelone glabra f. tomentosa (Рa.) 901, 6480, 8827, 886I, 8912.

Gratiola aurea (N. J.) 6500, 6527, 9929.

Gratiola aurea obtusa (N. J.) 9897.

Gratiola neglecta (Conn.) 8579. (N. Y.) 9930. (N. J.) 7367 ,

9445. (Ра.) I 495, 2822, 5013, 6477, 6994, 7256, 7861.

Gratiola pilosa (N. J.) 6486, 649I.

Gratiola virginiana (N. J.) $6+95$.

Hemianthus micranthus (N. J.) $6+97$.

Ilysanthes dubia (N. Y.) 6704 p.p., 8429. (N.J.) 6493. (Pa.) 6467,6474 p.p., 8014,8837 . 
Ilysanthes dubia inundata (N. J.) 6496.

Ilysanthes inaequalis (N. Y.) 6704 p.p. (N. J.) 3987, 6494, 6636. (Pa.) 6474 p.p.

Limosella subulata (N. J.) 6635.

Linaria canadensis (N. Y.) 7747, 10143. (N. J.) 6488, 6520, 6971, 6972, 8182, 9438, Іо0 12, 1002 I, 10077. (Md.) 8882.

Linaria Linaria (N. Y.) 6699, 7014, 7679, 8710. (N. J.) 6526, 6548, 7408. (Рa.) 7303, 7968. (Md.) 888I.

Melampyrum lineare (N. J.) 3572, 3818, 3836, 6499, 6522, 6587, $8 \mathrm{I} 67$, 9050. (Pa.) I883, 648I.

Melampyrum lineare latifolium (N. Y.) 6795, 6798, 8440. (N. J.)

7429, 92 I9, 9460, го010, I0054, гогі8. (Ра.) I56I, 650I, $6795,7880,7956,8852$.

Mimulus alatus (N. Y.) 7683, 8209.

Mimulus ringens (N. Y.) 6550, 6642, 6683, 7636, 8687, 9190,

9305. (N. J.) 6537. (Pa.) 6472, 6476, 6502, 7857, 7889, $8028,8842,8958$.

Otophylla auriculata (Pa.) 5229, 5230, 5285, 5290.

Pedicularis canadensis (N. Y.) 2386, 6761, 6823, 6905, 7153, 8433, 995I, 9968, гоI4I. (N. J.) 6974, 9995. (Ра.) 26I2, $6792,8753$.

Pedicularis lanceolata (Pa.) I 839, 6469.

Penstemon Digitalis (N. Y.) 9423. (Pa.) $647 \mathrm{r}$.

Penstemon hirsutus (N. J.) 7409. (Pa.) 3645, 6716, 7006.

Penstemon pallidus (N. Y.) $7 \mathrm{I} 30$.

Schwalbea americana (N. J.) 9028, 10086.

Scrophularia leporella (N. Y.) 6790, 6888, 6910, 7732, 8323.

(N.J.) 10098. (Pa.) 4993.

Scrophularia marilandica (N. Y.) 8220. (N. J.) 9904. (Pa.) 6468, 6504, 8108.

Verbascum Blattaria (N. J.) 7053. (Рa.) 6475, $797 \mathrm{I}$.

Verbascum Lychnitis (Pa.) 6478.

Verbascum Thapsus (N. Y.) 6684, 8324, 8496. (Рa.) 6479, 7970. Veronica americana (N. Y.) 6824, 6887, 7 I86, 7740. (N. J.) 6533, 9437. (Pa.) 5069, 7238.

Veronica arvensis (N. Y.) 6787, 6867. (N. J.) 7062, 9993. (Pa.) 6719, 6999, 7254. 
Veronica Brittonii (N. J.) Iогоо.

Veronica Chamaedrys (N. Y.) 6768.

Veronica officinalis (N. Y.) 6880, 7023,7 7 I $8,7623,8423$. (N. J.)

6528, 7414. (Рa.) 6718, 7965.

Veronica peregrina (Pa.) 6995.

Veronica scutellata (N. Y.) 664I.

Veronica serpyllifolia (N. Y.) 6788, 6830, 69I I.

Veronica Tournefortii (Pa.) 6466.

Veronicastrum virginicum (N. Y.) 773I, 8697, 985I. (N. J.)

6529, іого4. (Рa.) 373, 4980, 4981, 6470, 7778, 8003, 8082, $9000,9016$.

\section{Additions AND Corrections}

Page III, line I9.-Delete word "persistent." The tuberclelike base of the style lasts but a short time after anthesis, not until the fruit is mature.

Page i i i, last line.-Vi. Veroniceae, not "Digitaleae."

Page I I2, line 9.-Add word "usually" before "parasitic."

Page II2, line I9.-Add word "one" so as to read "Two stigmatic lines, one down each side of style-apex."

Page II2, line 22.-Add to characterization of genera contrasted with Buchnera, "Calyx not bracted at base."

Page I I3, line I2.-Add to characterization of Buchnera, " Calyx bibracteolate at base."

Page II3, line I9.-Add to characterization of Schwalbea: "Calyx bibracteolate at base."

Page I I3, line 22.-Add to characterization of genera contrasted with Schwalbea, "Calyx not bracted at base."

Page II4, line I0.-Add phrase "to four" so expression reads "Seeds maturing two to four to a capsule."

Page I52, line I3.-Add "Linaria canadensis occurs occasionally in a pink-flowered form."

Page I68.-I3. Veronica Brittonii Porter and Page I70.-I4. Veronica glandifera Pennell. It should have been stated that both these newly described species are segregates from the complex known as Veronica Anagallis-aquatica L. This name belongs to some one of several Palaeartic species, all of which differ from our plants. 

. 


\section{The New York Botanical Garden}

Journal of the New York Botanical Garden, monthly, illustrated, containing notes, news, and non-technical articles of general interest. Free to all members of the Garden. To others, Io cents a copy; \$1.00 a year. [Not offered in exchange.] Now in its twenty-first volume.

Mycologia, bimonthly, illustrated in color and otherwise; devoted to fungi, including lichens; containing technical articles and news and notes of general interest, and an index to current American mycological literature. \$4.00 a year; single copies not for sale. [Not offered in exchange.] Now in its twelf th volume.

Addisonia, quarterly, devoted exclusively to colored plates accompanied by popular descriptions of flowering plants; ten plates in each number, forty in each volume. Subscription price, \$10.00 a year. [Not offered in exchange.] Now in its fifth volume.

Bulletin of the New York Botanical Garden, containing the annual reports of the Director-in-Chief and other official documents, and technical articles embodying results of investigations carried out in the Garden. Free to all members of the Garden; to others, $\$ 3.00$ per volume. Now in its tenth volume.

North American Flora. Descriptions of the wild plants of North America, including Greenland, the West Indies, and Central America. Planned to be completed in 34 volumes. Roy. 8vo. Each volume to consist of four or more parts. Subscription price, \$I.50 per part; a limited number of separate parts will be sold for $\$ 2.00$ each. [Not offered in exchange.]

Vol. 3, part I, IgIo. Nectriaceae-Fimetariaceae.

Vol. 7, part I, 1906; part 2, 1907; part 3, I912. Ustilaginaceae-Aecidiaceae (pars). (Parts I and 2 no longer sold separately.)

Vol. 9 (now complete), parts I-7, I907-I9I6. Polyporaceae-Agaricaceae (pars). (Parts I- 3 no longer sold separately.)

Vol. 10, part I, I9I4; parts 2 and 3, I9I 7. Agaricaceae (pars).

Vol. I5, parts I and 2, I9I3. Sphagnaceae-Leucobryaceae.

Vol. 16, part I, I909. Ophioglossaceae-Cyatheaceae (pars).

Vol. 17, part I, I909; part 2, I912; part 3, 1915. Typhaceae-Poaceae (pars).

Vol. 2I, part I, I9I6; part 2, I9I7; part 3, I9I8. Chenopodiaceae-Allioniaceae.

Vol. 22, parts I and 2, 1905; parts 3 and 4, 1908; part 5, I9I3; part 6, I9I8. Podostemonaceae-Rosaceae.

Vol. 24, part I, I9I9. Fabaceae (pars).

Vol. 25, part I, 1907; part 2, I910; part 3, I9II. Geraniaceae-Burseraceae.

Vol. 29, part I, I9I4. Clethraceae-Ericaceae.

Vol. 32, part I, I9I8. Rubiaceae (pars).

Vol. 34, part I, I9I4; part 2, I9I5; part 3, I916. Carduaceae-Anthemideae.

Memoirs of the New York Botanical Garden. Price to members of the Garden, $\$$ I.50 per volume. To others, \$3.00. [Not offered in exchange.]

Vol. I. An Annotated Catalogue of the Flora of Montana and the Yellowstone Park, by Per Axel Rydberg. ix +492 pp., with detailed map. I900.

Vol. II. The Influence of Light and Darkness upon Growth and Development, by D. T. MacDougal. xvi +320 pp., with I 76 figures. 1903 .

Vol. III. Studies of -Cretaceous Coniferous Remains from Kreischerville, New York, by A. Hollick and E. C. Jeffrey. viii + I38 pp., with 29 plates. I909.

Vol. IV. Effects of the Rays of Radium on Plants, by Charles Stuart Gager. viii +278 pp., with 73 figures and I4 plates. I908.

Vol. V. Flora of the Vicinity of New York: A Contribution to Plant Geography by Norman Taylor. vi +683 pp., with 9 plates. I9I5.

Vol. VI. Papers presented at the Celebration of the Twentieth Anniversary of the New York Botanical Garden. viii +592 pp., with 43 plates and many text figures. I9I6.

Contributions from the New York Botanical Garden. A series of technical papers written by students or members of the staff, and reprinted from journals other than the above. Price, 25 cents each. $\$ 5.00$ per volume. In the ninth volume.

NEW YORK BOTANICAL GARDEN Bronx Park, New York City 